\title{
NOTE
}

\section{THE VOID-FOR-VAGUENESS DOCTRINE IN THE SUPREME COURT *}

\section{A Means to an End}

There are places in the law through which a pair of mutually oblivious doctrines run in infinitely parallel contrariety, like a pair of poolhall scoring racks on one or the other of which, seemingly at random, cases get hung up. ${ }^{1}$ Such is the area of those Supreme Court decisions ${ }^{2}$ which purport to turn on the issue of "unconstitutional uncertainty" 3 - decisions in which

* It would be dishonest or very naive not to recognize the heavy debt the author owes to Professor Paul Mishkin. He cannot be charged with any of the ideas this Note contains, nor can his reaction to them be anticipated. But the impression remains that so much of it as is intellectually satisfying derives from perspectivesor from methods of developing perspectives-which are held on loan from him.

1 Consider the paired canons of statutory construction that acts in derogation of the common law are to be strictly construed but that acts remedial of the common law are to be liberally construed. See Fordham \& Leach, Interpretation of Statutes in Derogation of the Common Lawe, 3 VAND. L. REV. 438 (1950). Or consider the tax law doctrines that a taxpayer may adopt devices to "minimize" but not to "evade" taxes. See Diamond A Cattle Co. v. Commissioner, 233 F.2d 739 (10th Cir. 1956). See also Horack, Constitutional Liberties and Statutory Construction, 29 Iowa I. Rev. 448 (1944); Llewellyn, Remarks on the Theory of Appellate Decision and the Rules or Canons About How Statutes Are to be Construed, 3 VAND. L. REV. 395 (1950).

2 Cases involving the issue of whether a statute is void or unenforceable for indefiniteness may be found in courts of all levels in all jurisdictions and are not peculiar to federal constitutional jurisprudence. Indeed, the thesis has been put forward that the development in federal law of the void-for-vagueness doctrine has nonconstitutional roots in the common-law practice of the judiciary to refuse enforcement to legislative acts deemed too uncertain to be applied. Aigler, Legislation in Vague or General Terms, 21 Micr. L. Rev. 831 (1923) ; Note, Constitutional Laze, Void for Vagueness: An Escape from Statutory Interpretation, 23 IND. L.J. 272 (1948). Compare Gellaorn, Administrative Law 160 (2d ed. 1947). Numerous federal cases decided before the turn of the twentieth century which treat vagueness as a problem of general criminal law not referable to any particular constitutional prescription bear this thesis out. See, e.g., United States v. Brewer, 139 U.S. 278 (1891); Tozer v. United States, 52 Fed. 917 (Brewer, Circuit Justice, 1892). More recent examples may be found of the Supreme Court's simply refusing to apply a federal statute whose terms it found incomprehensible, without seeking in the Bill of Rights authority to justify its refusal. United States v. Evans, 333 U.S. 483 (1948). Obviously, though, Supreme Court review of state criminal administration, which has been the most significant sphere of operation of the void-for-vagueness doctrine, cannot be supported on principles deriving directly from natural law or the jus gentiutm; whatever its initial origin, the doctrine must in these cases find its present foundation in the fourteenth amendment. This Note will concern itself exclusively with vagueness cases in the Supreme Court of the United States.

3 For general discussions of the doctrine, see Collings, Unconstitutional Uncertainty-An Appraisal, 40 CORNELL L.Q. 195 (1955); Note, Due Process Requirements of Definiteness in Statutes, 62 HARV. L. REV. 77 (1948). The source of a constitutional requirement of certainty is somewhat obscure. There are indications that the Court has on occasion tended to associate that doctrine with the sixth amend- 
the Court, passing upon state and federal statutes, ${ }^{4}$ has had to determine whether their "words and phrases are so vague and indefinite that any penalty prescribed for their violation constitutes a denial of due process of law." 5 On one hand, all are agreed that "a statute which either forbids or requires the doing of an act in terms so vague that men of common intelligence must necessarily guess at its meaning and differ as to its application, violates the first essential of due process . . ."; ${ }^{B}$ that "it will not do to hold an average man to the peril of an indictment for the unwise exercise of his . . . knowledge involving so many factors of varying effect that neither the person to decide in advance nor the jury to try him after the

ment's command that a criminal accused "be informed of the nature and cause of the accusation." See Yu Cong Eng v. Trinidad, 271 U.S. 500, 518 (1926); Mahler v. Eby, 264 U.S. 32, 41 (1924); United States v. L. Cohen Grocery Co., 255 U.S. 81, 89 (1921). But inasmuch as state criminal convictions have been reversed on void-forvagueness grounds despite very specific indictments, this ground is at best very questionable. See Lanzetta v. New Jersey, 306 U.S. 451,453 (1939); Herndon v. Lowry, 301 U.S. 242 (1937); Collings, supra at 204; Comment, Legislation-Requirement of Definiteness in Statutory Standards, 53 Mrcm. L. Rev. 264, 269 n.19 (1954). As regards federal statutes, a separation-of-powers notion has sometimes been invoked, predicated upon the proposition that it is improper for Congress to pass the lawmaking job to the judiciary. James v. Bowman, 190 U.S. 127 (1903); Trade-Mark Cases, 100 U.S. 82 (1879) ; United States v. Reese, 92 U.S. 214 (1875).

An analogy between void-for-vagueness doctrine and the common-law principle of nonenforcement of incomprehensible statutes has already been remarked, note 2 supra, and the further analogy to the common-law canon of strict construction of penal statutes is evident. See, e.g., McBoyle v. United States, 283 U.S. 25 (1931). See also Quarles, Some Statutory Construction Problems and Approaches in Crimirral Law, 3 VAND. L. REv. 531, 532, 539 (1950). The most articulate modern conception of the doctrine as a command of due process stresses two aspects: fair warning to the potential criminal offender, see $M r$. Justice Frankfurter, dissenting, in Winters v. New York, 333 U.S. 507, 524 (1948); and standards sufficiently precise to guide the court and jury in determining whether a crime has been made out, see Mr. Justice Roberts, dissenting, in Screws v. United States, 325 U.S. 91, 151-52, 154 (1945). See also Scott, Constitutional Limitations on Substantive Criminal Law, 29 Rocky Mr. L. REv. 275 (1957).

4 Although it is usual to conceive of the void-for-vagueness cases as cases in which the Supreme Court passes upon the "face" validity of statutes, in fact what the Court is far more frequently reviewing is a state court's reading of the challenged statute. See Winters v. New York, 333 U.S. 507 (1948); Bandini Petroleum Co. v. Superior Court, 284 U.S. 8 (1931). Such an interpretation may often differ quite radically from the statutory language itself. See Chaplinsky v. New Hampshire, 315 U.S. 568 (1942); Cox v. New Hampshire, 312 U.S. 569 (1941); cf. Yu Cong Eng v. Trinidad, 271 U.S. 500 (1926). In other vagueness cases the Court has passed not upon single statutes as construed but rather upon a corpus of state law made up of a judicial compost of three state statutes and a clause of the state constitution, International Harvester Co. of America v. Kentucky, 234 U.S. 216 (1914), a state judicial application of the common-law crime of inciting a breach of the peace, Cantwell v. Connecticut, 310 U.S. 296 (1940), and a disorderly conduct conviction based, in turn, upon defendant's disobedience of an unwritten municipal custom, Niemotko v. Maryland, 340 U.S. 268 (1951). See also Watkins v. United States, 354 U.S. 178 (1957), where vagueness was imported into a statute relatively defnite on its face by a chain of affairs in the several-year history of a legislative investigatory committee and its subcommittees. The more general case, however, involves consideration of a state statute as construed, and unless indicated, that is the situation which will be intended when this Note speaks of the Court's passing on state "legislation." The considerations in instances of federal statutory vagueness are significantly different from those of state vagueness. See notes $92-97$ infra and accompanying text.

5 Champlin Ref. Co. v. Corporation Comm'n, 286 U.S. 210, 243 (1932).

6 Connally v. General Constr. Co., 269 U.S. 385, 391 (1926). 
fact can safely and certainly judge the result." 7 On the other hand, there has never been dissent from Mr. Justice Holmes' observation that "the law is full of instances where a man's fate depends on his estimating rightly, that is, as the jury subsequently estimates it, some matter of degree. If his judgment is wrong, not only may he incur a fine or a short imprisonment . . . ; he may incur the penalty of death." 8

One of the two former quotations is from Cline v. Frink Dairy Co., ${ }^{9}$ which held unconstitutional a statute that outlawed certain agreements and associations in restraint of trade, excepting those whose object was to market at "a reasonable profit" products which could not otherwise be so marketed. ${ }^{10}$ That case followed its more famous ancestor, United States $v$. L. Cohen Grocery Co., ${ }^{11}$ which had voided for vagueness section 4 of the Lever Act," proscribing the making of "any unjust or unreasonable rate or charge in handling . . . any necessaries." The counter-sounding Holmes quotation is from Nash v. United States, ${ }^{13}$ sustaining as a sufficiently definite criminal standard the "rule of reason" 14 of the Sherman Act ${ }^{15}$ - a case which fathered such others as Edgar A. Levy Leasing Co. v. Siegel,,$^{18}$ upholding state rent control legislation which allowed as a defense

7 Cline v. Frink Dairy Co., 274 U.S. 445, 465 (1927).

8 Nash v. United States, 229 U.S. 373, 377 (1913).

9274 U.S. 445 (1927).

10 Colo. Acts 1913, ch. 161.

11255 U.S. 81 (1921).

12 Ch. 53, 40 Stat. 277 (1919), as amended, ch. 80, 41 Stat. 297 (1919).

13229 U.S. 373 (1913).

14 Standard Oil Co. v. United States, 221 U.S. 1 (1911), and United States v. American Tobacco Co., 221 U.S. 106 (1911), read into $\$ 1$ of the Sherman Act, 26 Stat. 209 (1890), as amended, 15 U.S.C. $\$ 1$ (1958), the qualification that a combination must be in "undue" or "unreasonable" restraint of trade to be unlawful under that act. Cline attempts to distinguish the "reasonable" restraint cases on the ground that Sherman Act "reasonableness" is of a more objective sort than that involved in the "reasonable profit" statute at bar. In this analysis it relies heavily on United States v. Addyston Pipe \& Steel Co., 85 Fed. 271 (6th Cir. 1898), modified, 175 U.S. 211 (1899), and the common-law test of "no main lawful purpose, to subserve which partial restraint is permitted," 85 Fed. at 283, which that case adopted. Yet in the same year in which Cline was decided, Mr. Justice Stone wrote for the Court in United States v. Trenton Potteries Co., 273 U.S. 392, 397 (1927) : "Reasonableness is not a concept of definite and unchanging content. Its meaning necessarily varies in the different fields of the law, because it is used as a convenient summary of the dominant considerations which control in the application of legal doctrines. ... Whether this type of restraint is reasonable or not must be judged in part at least in the light of its effect on competition ...." And as to the certainty of an effecton-competition test, comparison of American Column \& Lumber Co. v. United States, 257 U.S. 377 (1921), with Maple Flooring Mfrs. Ass'n v. United States, 268 U.S. 563 (1925), should have put the Cline Court on notice that the happy but specious simplicities of Addyston concealed the most intricate, manifold, and unobjective of evaluations. See United States v. Associated Press, 52 F. Supp. 362, 370 (S.D.N.Y. 1943) (L. Hand, J.), aff'd, 326 U.S. 1 (1945): "Congress has incorporated into the Anti-Trust Acts the changing standards of the common law, and by so doing has delegated to the courts the duty of fixing the standard for each case."

15 Sherman Antitrust Act $\$ 1,26$ Stat. 209 (1890), as amended, 15 U.S.C. §1 (1958).

16258 U.S. 242 (1922). Levy Leasing was a civil case, and in its one line distinction of Cohen ("[Cohen], dealing with definitions of crime, is not applicable," 258 U.S. at 250) seemed to stand for the proposition that the rule of that case was limited 
to a landlord's action his tenant's showing that the rent charged was "unjust and unreasonable," ${ }^{17}$ and United States $v$. Ragen, ${ }^{18}$ sustaining a conviction for federal income tax evasion predicated upon the defendant's having taken a deduction which violated the statutory mandate that only a "reasonable allowance for salaries" 18 might be excluded from taxable income. The difference between Cohen-Cline and Nash-Ragen-Levy Leasing is not merely one of drawing a line. Line-drawing is the nature of the judicial process, constrained as it is to reach some categorical result in each of a series of cases along a continutum. But while the propriety of placing the line at a particular point may not be rationally demonstrable, in the usual line-drawing area judicial opinions do articulate the countervailing pressures which require that a line be drawn somewhere, do explore the considerations which delimit, on either side, at least the broad range within which it must be drawn, and do relate these considerations to the facts of the individual case. ${ }^{20}$ Such is not the situation, however, with regard to the void-for-vagueness decisions. What gives these decisions their poolrack-hung-up appearance is their almost habitual lack of informing rea-

to criminal proceedings. This intimation caused the Court considerable trouble when, in A. B. Small Co. v. American Sugar Ref. Co., 267 U.S. 233 (1925), the same \&4 of the Lever Act, ch. 53, 40 Stat. 277 (1919), as amended, ch. 80, 41 Stat. 297 (1919), which it had held unconstitutional in Cohen and companion cases was urged as a defense in a civil contract action. The Court followed the earlier Lever Act cases and held the defense impermissible, saying that the Cohen principle "was not such as to be applicable only to criminal prosecutions. It was not the criminal penalty that was held invalid, but the exaction of obedience to a rule or standard which was so vague and indefinite as really to be no rule or standard at all." 267 U.S. at 239. In so holding, the Court had in effect to redecide (or at least rerationalize) Levy Leasing, which was now put on the ground that a "reasonable rent" was a more objectively ascertainable quantity than a "reasonable profit."

To say that the void-for-vagueness rule is applicable to noncriminal proceedings, however, is not to say that the seriousness of what is at stake will not be an extremely significant variable (among others) in the determination of whether a statute will survive a vagueness attack. All other factors being equal, it is probable that a statute imposing penal sanctions will be looked at more severely than one whose operation is of less drastic effect, and the same principle should apply where all other factors are unequal, as they always are. Winters v. New York, 333 U.S. 507, 515 (1948), contains language to the effect that "the standards of certainty in statutes punishing for offenses is [sic] higher than in those depending primarily upon civil sanction for enforcement," and it is indicative that except in Small (which was a case put in a unique posture by such previous holdings as (ohen), no vagueness attack on a noncriminal statute has succeeded. See Adler v. Board of Educ., 342 U.S. 485 (1952) (cause for dismissal from public employment) ; Jordan v. De George, 341 U.S. 223 (1951) (deportation) ; American Communications Ass'n v. Douds, 339 U.S. 382 (1950) (withdrawal of protection of NLRB) ; Minnesota ex rel. Pearson v. Probate Court, 309 U.S. 270 (1940) (civil lunacy commitment); Old Dearborn Distrib. Co. v. Seagram-Distillers Corp., 299 U.S. 183 (1936) (civil damages and injunction from underselling fair-trade prices) ; Baltimore \& O.R.R. v. Groeger, 266 U.S. 521 (1925) (civil liability); Miller v. Strahi, 239 U.S. 426 (1915) (civil liability). Compare the discussion in note 78 infra.

17 N.Y. Sess. Laws 1920 , ch. $944, \S 1$.

18314 U.S. 513 (1942).

19 Revenue Act of 1932, ch. 209, §145, 47 Stat. 217.

20 Consider, for example, the Court's recent abstention decisions, such as Louisiana Power \& Light Co. v. City of Thibodaux, 360 U.S. 185 (1959). 
soning. ${ }^{21}$ It is common in the cases which sustain a statute against the charge of vagueness to say merely that it is "as definite as" a statute sustained in some earlier case ${ }^{22}$-an argument which, in view of the fact that the earlier case expresses no criterion of definiteness, is singularly unilluminating. Other cases state only their conclusion-that the statute is too uncertain (or not too uncertain)-and cite in support earlier decisions, not dealing with statutes of similar wording or even of similar sphere of operation, ${ }^{23}$ but rather laying down the broadly phrased, black letter, polar doctrines, Cohen or Nash, one or the other. ${ }^{24}$ One leading void-for-vagueness decision distinguished cases in which statutes had been upheld because "for reasons found to result either from the text of the statutes involved or the subjects with which they dealt, a standard of some sort was afforded." ${ }^{25}$ Subsequent statute-sustaining decisions are fond of quoting this passage for their sole justification, without bothering to intimate what standard, or of what sort, or by what reasons, or whether from "text" or "subject," certainty is derived. ${ }^{26}$

21 See, e.g., Cole v. Arkansas, 338 U.S. 345 (1949). The state statute made it unlawful "for any person acting in concert with one or more persons, to assemble at or near any place where a 'labor dispute' exists and by force or violence prevent or attempt to prevent any person from engaging in any lawful vocation, or for any person acting either by himself, or as a member of any group or organization or acting in concert with one or more other persons, to promote, encourage or aid any such unlawful assemblage. . . " ARK. STAт. ANN. \$81-207 (1960). Both the indictment and the jury charge were in the precise words of the statute, and defendant was convicted. The Supreme Court affirmed, rejecting an argument of vagueness with a reiteration of the identical words used by the act, the prosecuting attorney, and the trial judge. See $i d$. at 354 .

22 See United States v. Harriss, 347 U.S. 612, 624 n.15 (1954); Minnesota ex rel. Pearson v. Probate Court, 309 U.S. 270, 274 (1940) ; Whitney v. California, 274 U.S. 357, 369 (1927) ; Omaechevarria v. Idaho, 246 U.S. 343, 348 (1918). See also Weeds, Inc. v. United States, 255 U.S. 109 (1921). Compare Beauharnais v. Illinois, 343 U.S. 250 (1952); Old Dearborn Distrib. Co. v. Seagram-Distillers Corp., 299 U.S. 183 (1936); Edgar A. Levy Leasing Co. v. Siegel, 258 U.S. 242 (1922). The type of reasoning-or lack of it-exemplified by the comparisons invited by these opinions is to be distinguished from similar sounding "as definite as" reasoning in cases such as Dennis v. United States, 341 U.S. 494 (1951) ; Baltimore \& O.R.R. v. Groeger, 266 U.S. 521 (1925); Waters-Pierce Oil Co. v. Texas, 212 U.S. 86 (1909). These latter cases, in language of comparison, appear in fact to be making an argument to necessity: that no other equally practical formulation is any clearer. See discussion of this principle of necessity in notes 150-51 infra and accompanying text.

23 See also cases cited note 22 supra. Harriss, involving lobbying, cites, among others, cases in which the contested statutes related to antitrust, sheep grazing, explosive hauling, coercion of employers to hire unnecessary labor, civil rights, and subversive activities. Whitney, involving a criminal syndicalism act, cites Nash (antitrust rule of reason) and Miller v. Shrahl, 239 U.S. 426 (1915) (innkeepers' liability to "do all in their power" to save guests in fire). Pearson, concerning a statute for commitment of "sexual psychopaths," cites Nash and adds sheep-grazing and political-fund-soliciting statutes.

24 See Roth v. United States, 354 U.S. 476, 491 (1957) (obscenity), citing Nash and Hygrade Provision Co. v. Sherman, 266 U.S. 497 (1925) ("kosher" not too indefinite); Miller v. Oregon, 273 U.S. 657 (1927) (per curiam) (automobile manslaughter), citing Nash.

25 Connally v. General Constr. Co., 269 U.S. 385, 391 (1926).

28 See, e.g., Old Dearborn Distrib. Co. v. Seagram-Distillers Corp., 299 U.S. 183,196 (1936). 
Indeed, from the Court's cavalier treatment of many a vagueness argument-dismissal in one this-contention-is-without-merit sentence ${ }^{27}$ or even footnote ${ }^{28}$-it is apparent that the doctrine is frequently argued as a makeweight. But in a significant number of cases, not articulately distinguished from those in which a plea of vagueness is rejected out of hand or even mocked, ${ }^{29}$ the Court seizes upon the makeweight and makes it the ratio decidendi. ${ }^{30}$ The result is not only a number of evident disharmonies

27 United States v. Kahriger, 345 U.S. 22 (1953) ; cf. United States v. Alford, 274 U.S. 264 (1927).

28 United States v. Korpan, 354 U.S. 271, 273 n.2 (1957). The decisive factor in this decision seems to have been that defendant was evidently exploiting the ambiguity complained of-in a taxing statute-to his own advantage. If so, the rationale might helpfully have been articulated. Summary treatment of Korpan, in light of cases such as McBoyle v. United States, 283 U.S. 25 (1931), is not edifying.

29 See the remark in footnote in Chaplinsky v. New Hampshire, 315 U.S. 568, 574 n.8 (1942), to the effect that defendant, an evangelist Jehovah's Witness, "need not . . . have been a prophet to understand what the statute condemned."

30 Compare United States v. Shreveport Grain \& Elevator Co., 287 U.S. 77 (1932) (incredibly strained statutory construction to avoid indefiniteness of "reasonable variations" standard in act requiring marked weights), with Boyce Motor Lines, Inc. v. United States, 342 U.S. 337 (1952) (carrier of explosives shall avoid "so far as practicable" congested routes; regulation sustained), autd Sproles v. Binford, 286 U.S. 374 (1932) ("shortest practicable route"; statute sustained). Compare Thornhill v. Alabama, 310 U.S. 88 (1940), with Fox v. Washington, 236 U.S. 273 (1915), and Burns v. United States, 274 U.S. 328 (1927). And compare Pierce v. United States, 314 U.S. 306 (1941), and McBoyle v. United States, 283 U.S. 25 (1931), and United States v. Pennsylvania R.R., 242 U.S. 208 (1916), with United States v. Alpers, 338 U.S. 680 (1950), and Gorin v. United States, 312 U.S. 19 (1941), and United States v. Alford, 274 U.S. 264 (1927). See Mr. Justice Jackson's dissent in Murdock v. Pennsylvania, 319 U.S. 105 (1943), and Martin v. Struthers, 319 U.S. 141 (1943), paged with the opinion in Douglas v. Jeannette, 319 U.S. 157, 175 (1943). It is not suggested that because a particular constitutional argument is a makeweight on the facts of one case that it will be a makeweight in all cases. But when the Court in case $X$ completely overlooks elements of vagueness which create severe constitutional problems in factually similar case $Y$, there arises some reason to believe that the compelling force behind $Y$ is not what it appears to be in the opinion. Similar considerations are present where a device is found in case $Y$ to avoid the charge of indefiniteness, while the same device, equally available on the facts of case $Z$, is there ignored. Compare the approval, insofar as vagueness is concerned, of the statutes in Ex parte Webb, 225 U.S. 663 (1912) (uncertain implied exemption from territorial liquor control), and United States v. Five Gambling Devices, 346 U.S. 441 (1953) (registration with attorney general "in such district"; no provision for determining what district was meant), with $\mathrm{Yu}$ Cong Eng v. Trinidad, 271 U.S. 500 (1926) (Philippine statute construed by the Philippine Supreme Court to command that only such commercial account books as are necessary for purposes of tax investigation need be kept in one of certain named languages of which Chinese was not one, voided for vagueness for want of definition of "necessary"). It is clear that in $W e b b$, as in Gambling Devices, the Justices of the Court were quick to find a method whereby a statutory unclarity (which it was no doubt felt that the individual defendant was attempting to manipulate to his own evasive advantage) could be illumined-by state denomination of those exempted, in $W e b b$; by existing regulations issued by the Attorney General which state his whereabouts for purposes of the act, in Gambling Devices. In $Y u$ Cong Eng it is equally clear that the large blanket of tolerance which the Court desired to throw about the Chinese, against whom the legislature had already tried to discriminate, forbade the discovery of any such illumining gimmick. Note that $Y u$ Cong Eng struck down the statute despite the fact that regulations as to what books were "necessary" almost certainly would have been forthcoming from the tax collecting authorities. Note also that to find such a gimmick would not have resulted in the mousetrapping of the individual Chinese merchants in the case before the Court; the proceeding was not a government enforcement action but an anticipatory suit by the merchants to enjoin the administration of the act. 
within the body of cases that talk "vagueness" 31 but also a number of instances of equally evident similarity between some of the vagueness cases and others which do not employ a vagueness syntax. ${ }^{32}$ Moreover, where the opinions do attempt to expound some policy bases for the doctrine, the holdings often fail to bear these bases out: it is common ground, for example, to explain the antivagueness prescription as a constitutional mandate that "no one may be required at peril of life, liberty or property to speculate as to the meaning of penal statutes. All are entitied to be informed as to what the State commands or forbids." 33 Yet the Supreme Court, in passing on these penal statutes, has invariably allowed them the benefit of whatever clarifying gloss state courts may have added in the course of litigation of the very case at bar. ${ }^{34}$ This would indicate, incon-

31 See the groups of cases cited in note 30 supra. Compare Cline v. Frink Dairy Co., 274 U.S. 445 (1927), and United States v. L. Cohen Grocery Co., 255 U.S. 81 (1921), with Nash v. United States, 229 U.S. 373 (1913). Compare A. B. Small Co. v. American Sugar Ref. Co., 267 U.S. 233 (1925), with Edgar A. Levy Leasing Co. v. Siegel, 258 U.S. 242 (1922). Compare Whitney v. California, 274 U.S. 357 (1927), and Burns v. United States, 274 U.S. 328 (1927), with Herndon v. Lowry, 301 U.S. 242 (1937). Compare Roth v. United States, 354 U.S. 476 (1957), with Joseph Burstyn, Inc. v. Wilson, 343 U.S. 495 (1952). Compare United States v. Petrillo, 332 U.S. 1 (1947), with Connally v. General Constr. Co., 269 U.S. 385 (1926). Compare the treatment of the standing issue in Williams v. United States, 341 U.S. 97 (1951), and Fox v. Washington, 236 U.S. 273 (1915), with the treatment of the same issue in Thornhill v. Alabama, 310 U.S. 88 (1940).

32 Compare Kingsley Int'l Pictures Corp. v. Regents of Univ. of N.Y., 360 U.S. 684 (1959), with Joseph Burstyn, Inc. v. Wilson, 343 U.S. 495 (1952). Compare De Jonge v. Oregon, 299 U.S. 353 (1937), and Fiske v. Kansas, 274 U.S. 380 (1927), with Herndon v. Lowry, 301 U.S. 242 (1937). Compare Terminiello v. Chicago, 337 U.S. 1 (1949), with Stromberg v. California, 283 U.S. 359 (1931). Compare Niemotko v. Maryland, 340 U.S. 268 (1951), with Fowler v. Rhode Island, 345 U.S. 67 (1953).

33 Lanzetta v. New Jersey, 306 U.S. 451,453 (1939).

34 See Poulos v. New Hampshire, 345 U.S. 395 (1953); Beauharnais v. Illinois, 343 U.S. 250 (1952) (state characterization rather than construction); Cole v. Arkansas, 338 U.S. 345 (1949) ; Chaplinsky v. New Hampshire, 315 U.S. 568 (1942); Cox v. New Hampshire, 312 U.S. 569 (1941) ; cf. Fox v. Washington, 236 U.S. 273 (1915) (Court gives statute benefit of "presumption" as to probable state court construction). In Musser v. Utah, 333 U.S. 95 (1948), defendants, Mormons who advised and counseled other members of their sect to practice polygamy, had been convicted under a statute, UTAB CODE ANN. \& 76-12-1 (1953), penalizing conspiracy "to commit any act injurious to the public health, to public morals, or to trade or commerce, or for the perversion or obstruction of justice or the due administration of the laws." While noting that statute "standing by itself . . . would seem to be warrant for conviction for agreement to do almost any act which a judge and jury might find at the moment contrary to his or its notions of what was good for health, morals, trade, commerce, justice or order," 333 U.S. at 97 , the majority of the Court voted to remand the case to the Utah courts to allow them first to construe and pass upon the statute as against specific void-for-vagueness attack. See also Rescue Army v. Municipal Court, 331 U.S. 549 (1947), refusing as premature the exercise of the Court's appeal jurisdiction in a case originating with a petition to a state appellate court for a writ of prohibition to terminate pending criminal proceedings.

These decisions reflect in part, no doubt, the same temper of federal deference to state court shaping of state law as is witnessed by such abstention decisions as Harrison v. NAACP, 360 U.S. 167 (1959), and Government \& Civic Employees Comm. v. Windsor, 353 U.S. 364 (1957), and exemplified in the course of litigation in Lassiter v. Northampton County Bd. of Elections, 360 U.S. 45 (1959). Compare Douglas v. Jeannette, 319 U.S. 157 (1943), with Murdock v. Pennsylvania, 319 U.S. 105 (1943). But while this may be a judicious policy where the federal right in question is one which will be infringed, if at all, by the continuing subordination of 
sistently with the "warning" rationale, that "the defendant, at the time he acted, was chargeable with knowledge of the scope of subsequent interpretation." 35 Nor is this practice of the Court- "for the purpose of deciding the constitutional questions . . . [taking] the statute as though it read precisely as the highest court of the State has interpreted it" 36 quite compatible with another claimed foundation for the vagueness doctrine: that "it would certainly be dangerous if the legislature could set a net large enough to catch all possible offenders and leave it to the courts to step inside and say who could be rightfully detained and who should be set at large." 37 These several circumstances indicate that vagueness alone, although helpful and important, does not provide a full and rational explanation of the case development in which it appears so prominently. Together with certain further indications which may be derived from the history of the doctrine ${ }^{38}$ and from the settings in which it is invoked

individual to state governmental interests which is represented in the ultimate balance at which state litigation terminates, it is certainly inappropriate where the federal right is-as traditional void-for-vagueness theory explains-a right to fair warning at a point in time prior to the state court litigation and contemporaneous with the act which the state seeks to punish. In other classes of cases where a federal right turns upon the status of state law as of a given moment in the past-or, more exactly, the appearance to the individual of the status of state law as of that moment-the Supreme Court has both declared and exercised its duty to make its own independent evaluation of what that law was (how it then looked) uninfluenced by subsequent state court interpretations. See Indiana ex rel. Anderson v. Brand, 303 U.S. 95 (1938) (interpretation of state law for purposes of federal constitutional impairment of contracts claim). A striking recent instance is NAACP v. Alabama ex rel. Patterson, 357 U.S. 449 (1958), in which, on writ of certiorari, the state argued that the Supreme Court's jurisdiction was defeated by the presence of an adequate and independent nonfederal ground for the state court decision, viz., that petitioner had pursued the wrong appellate remedy at state law. Rejecting this contention, the Supreme Court found that in cases similar to the one at bar the Alabama court had allowed appellate review in the mode chosen by petitioner. In response to the state's argument that those earlier cases were distinguishable, the Court admitted that this might be so but found it immaterial inasmuch as the apparent condition of state procedural law at the time petitioner made its election of remedies did not sufficiently clearly suggest the distinctions advanced as to put petitioner on notice. Id. at $457-58$.

35 Winters v. New York, 333 U.S. 507, 514-15 (1948) (dictum). As Winters and Kunz v. New York, 340 U.S. 290 (1951), demonstrate, post hoc state construction may be heavily relied on by the Court in striking down, as well as in sustaining, a challenged statute. Such reliance for purposes of voiding is of course not, as is saving reliance, inconsistent with the fair warning rationale.

36 Minnesota ex rel. Pearson v. Probate Court, 309 U.S. 270, 273 (1940).

37 United States v. Reese, 92 U.S. 214, 221 (1875).

38 The void-for-vagueness doctrine was born in the reign of substantive due process and throughout that epoch was successfully urged exclusively in cases involving regulatory or economic-control legislation. Champlin Ref. Co. v. Corporation Comm'n, 286 U.S. 210 (1932); Smith v. Cahoon, 283 U.S. 553 (1931); Cline v. Frink Dairy Co., 274 U.S. 445 (1927) ; Connally v. General Constr. Co., 269 U.S. 385 (1926) ; A. B. Small Co. v. American Sugar Ref. Co., 267 U.S. 233 (1925) ; United States v. L. Cohen Grocery Co., 255 U.S. 81 (1921), and companion cases; American Seeding Mach. Co. v. Kentucky, 236 U.S. 660 (1915); Malone v. Kentucky, 234 U.S. 639 (1914); Collins v. Kentucky, 234 U.S. 634 (1914); International Harvester Co. of America v. Kentucky, 234 U.S. 589 (1914); International Harvester Co. of America v. Kentucky, 234 U.S. 216 (1914). Vagueness contentions in free speech cases received short shrift at that time. Fox v. Washington, 236 U.S. 273 (1915), which, after Kingsley Int'l Pictures Corp. v. Regents of Univ. of N.Y., 360 U.S. 684 (1959) (per curiam), is at best extremely questionable law today; Mutual Film 
successfully, 39 they rather compel the conclusion that in the great majority of instances the concept of vagueness is an available instrument in the service of other more determinative judicially felt needs and pressures. It is the purpose of this Note to discuss those other pressures and to attempt to discover under what conditions the vehicle of vagueness will be utilized to aid in meeting their demands.

\section{Clearance Space for Individual Freedoms}

The primary thesis advanced here is that the doctrine of unconstitutional indefiniteness has been used by the Supreme Court almost invariably for the creation of an insulating buffer zone of added protection at the peripheries of several of the Bill of Rights freedoms. With regard to one class of cases, those involving potential infringement of first amendment privileges, this buffer-zone principle has always been expressly avowed in the Court's opinions ${ }^{40}$ and recognized by the commentators. ${ }^{41}$ But this

Corp. v. Industrial Comm'n, 236 U.S. 230 (1915), since overruled by Superior Films, Inc. v. Department of Educ., 346 U.S. 587 (1954) (per curiam). Since the advent of the New Deal Court, by contrast, there has been one economic vagueness case, and with the ever increasing emphasis upon protection of first amendment liberties, free speech vagueness cases have begun to proliferate. E.g., Watkins v. United States, 354 U.S. 178 (1957) ; Joseph Burstyn, Inc. v. Wilson, 343 U.S. 495 (1952) ; Niemotko v. Maryland, 340 U.S. 268 (1951); Winters v. New York, 333 U.S. 507 (1948).

39 Notice that in none of the cases cited in note 38 supra except Comrally was vagueness the sole ground of constitutional invalidation urged; in each there lurked some other more or less tenable claim of liberty from government restraint. Consider especially Mr. Justice Holmes' evident sympathy with the confiscation and equal economic protection claims in International Harvester; the Court's begrudging recognition of the extension of the congressional war powers into the technically still-at-war postwar period of Coheit, and Small's substantive due process sounding gloss on that case; the strong expropriation argument in Champlin; the recurrence of the equal protection claim in Cline. Compare Chicago \& N.W. Ry. v. Dey, 35 Fed. 866 (Brewer, Circuit Judge, 1888). And the so-called first amendment vagueness cases are precisely what that name implies. See Thornhill v. Alabama, 310 U.S. 88 (1940); Herndon v. Lowry, 301 U.S. 242 (1937); Stromberg v. California, 283 U.S. 359, 369 (1931) ; Kingsley Int'1 Pictures Corp. v. Regents of Univ. of N.Y., 360 U.S. 684, 694-95 (1959) (Frankfurter, J., concurring). That in any given case a claimant's substantive due process argument might not have been strong enough to carry, or that the particular communication for which he claimed freedom of expression might not have been within the realm of absolute immunity of the first amendment, is not indicative of the compelling force exerted by the presence of these claims in the vagueness context. Of course, had each of the claims carried sufficient conviction to determine the outcome independently, the vagueness syntax need never and probably would never-have been used. It becomes necessary inasmuch as the individual claimant fails definitively to establish that his economic or expressive interests have been unconstitutionally curtailed, and especially since that failure is precipitated by the want of defining certainty of the statute he is attacking. See note 72 infra and accompanying text.

40 See cases cited note 39 supra; Watkins v. United States, 354 U.S. 178, 197-98 (1957); Winters v. New York, 333 U.S. 507, 509-10 (1948); United States v. CIO, 335 U.S. 106, 140-42, 146, 150-53 (1948) (Rutledge, J., concurring) ; United States v. Harriss, 347 U.S. 612, 632 (1954) (Douglas, J., dissenting). The rationale has most recently been described by Mr. Justice Brennan for the Court in Smith v. California, 361 U.S. 147, 150-51 (1959): "[T] his Court has intimated that stricter standards of permissible statutory vagueness may be applied to a statute having a potentially inhibiting effect on speech; a man may the less be required to act at his peril here, because the free dissemination of ideas may be the loser."

41 E.g., Collings, supra note 3, at 218-19; Note, supra note 2, at 284. 
is not to say, as some of the commentators have said, ${ }^{42}$ that there are two wholly separate and differently grounded kinds of vagueness decision: the "true" uncertainty case like Cohen, Cline, Connally v. General Constr. Co., ${ }^{43}$ Lanzetta v. New Jersey, ${ }^{44}$ or International Harvester Co. of America v. Kentucky, ${ }^{45}$ in which a legislature which might constitutionally have proscribed either or both of two classes of behavior, $A$ and $B$, has chosen to proscribe only $A$, but in language so uncertain that whether most fact situations are $A$ or $B$ is a matter for guesswork; and the "spurious" uncertainty cases like Herndon $v$. Lowry, ${ }^{46}$ Watkins $v$. United States, ${ }^{47}$ or Winters v. New York, ${ }^{48}$ in which a legislature, constitutionally free to regulate sphere $A$, but forbidden to encroach upon sphere $B$, has included indiscriminately within the broad wording of a criminal statute both $A$ cases and $B$ cases, thereby leaving the individual to guess at his peril whether he can or cannot be constitutionally punished for violation of the statute. The evil in the first kind of case is said to be lack of fair warning and of a standard for the adjudication of guilt; ${ }^{49}$ in the second, the threat that the statutes' "broad language may throttle protected conduct. They have a coercive effect since rather than chance prosecution people will tend to leave utterances unsaid even though they are protected by the Constitution." so

This analysis, while pointing up a significant distinction, leaves much unaccounted for. In the first place, it is obvious that some of the "spurious" uncertainty cases are as firmly grounded upon the felt want of fair notice as the "true" uncertainty cases, the unfairness residing in the very indefiniteness of the line of constitutional safety. ${ }^{51}$ Second, there is a line of "spurious" uncertainty cases, from Lovell v. Griffin 52 to Joseph Burstyn, Inc. v. Wilson ${ }^{53}$ and Gelling v. Texas,",4 which can not be rested wholly

42 Barrett, Bruton \& Honnold, Constitutional Law 731 (1959); Collings, supra note 3, at 220; Bernard, Avoidance of Constitutional Issues in the United States Supreme Court: Liberties of the First Amendment, 50 MicH. L. REv. 261, 274-77 (1951).
43269 U.S. 385 (1926).
44306 U.S. 451 (1939).
45234 U.S. 216 (1914).
46301 U.S. 242 (1937).
47354 U.S. 178 (1957).
48333 U.S. 507 (1948).

49 Collings, supra note 3 , at 218. Accord, Scott, supra note 3, at 288; Note, 62 Harv. L. Rev. 77 (1948). Quarles, supra note 3, at 541-42, argues that "as a practical matter a statute apprising the individual can be made to apprise the court and jury. It does not seem likely that a court will be unable to make a determination the individual can make. Therefore, the important function in the requirement of definiteness of a criminal statute is to give notice to the individual."

50 Collings, supra note 3 , at 219.

51 Winters, 333 U.S. at 519-20; Herndon, 301 U.S. at 261-62; United States v. CIO, 335 U.S. 106, 142, 147, 150-51 (1948) (Rutledge, J., concurring). Compare the passage from Smith v. Cahoon, 283 U.S. 553, 564 (1931), cited in text at note 62 infra.

52303 U.S. 444 (1938).

53343 U.S. 495 (1952).

54343 U.S. 960 (1952) (per curiam). 
upon either no fair warning or deterrence of protected conduct inasmuch as the statutory language there found overly vague was not language fixing a standard of criminal conduct but language empowering an administrative or executive authority to fix, by unmistakably specific action, the lawfulness or unlawfulness of defined particular conduct. ${ }^{55}$ On the other hand, the so-called "true" cases, when seen in their historical perspective, contain many of the elements of the spurious line. Most of them date from an era when economic laissez faire ${ }^{56}$ was for the Court the sanctum sanctorum that free speech has become today, ${ }^{67}$ and decisions like Cohen and International Harvester display unmistakable signs of the same extraneous constitutional compulsion which marks Watkins and Winters. ${ }^{58}$ Perhaps the best example of this is Smith $v$. Cahoon, ${ }^{59}$ a 1931 decision voiding Florida's motor transport statute. That act, a comprehensive regulatory scheme including licensed entry, safety and insurance controls, and rate-fixing provisions, was applicable by its terms to "every operation or person . . . owning, controlling, operating or managing any motor-propelled vehicle . . . used in the business of transporting persons or property for compensation or as a common carrier over any public highway . . . between fixed termini or over a regular route." 60 Smith was what would be called today a contract carrier : a trucker not holding himself out for public service but employed under an exclusive contract with a single large shipper. Arrested for operating without having applied for a license and paying the license $\operatorname{tax}$ as required by the statute, he brought state habeas corpus proceedings to test the act's applicability to him and its validity as so

55 Since such administrative action is judicially reviewable, e.g., pursuant to N.Y. Civ. PRAC. AcT \$ 78, Joseph Burstyn, Inc. v. Wilson, 303 N.Y. 242, 101 N.E.2d 665 (1951), its constitutional permissibility vel non may be authoritatively established prior to any act of disobedient conduct, and the individual is not held "to the peril of an indictment." See text at note 6 supra. Of course it might be argued that the necessity of pursuing such proceedings as a prerequisite to vindication of first amendment rights is itself such an impediment to the exercise of those rights as to be constitutionally impermissible. This contention would seem effectively foreclosed-at least insofar as the statute is not "void on its face"-by Poulos v. New Hampshire, 345 U.S. 395 (1953).

56 See note 38 supra. See generally Borchard, The Supreme Court and Private Rights, 47 YALE L.J. 1051 (1938). Contemporary comment was not slow to take notice of the similarity of the operation of void-for-vagueness and substantive due process in the economic legislation cases. Note, Indefinite Criteria of Definiteness in Statutes, 45 HARv. L. REv. 160, 162 (1931).

57 See Bernard, supra note 42, at 266-69 with his extensive collection of authority in footnotes $31-40$.

58 See note 39 supra. It would seem more than a coincidence that the pattern of dissent in these cases followed the lines of cleavage of economic thinking on the Court. Mr. Justice Pitney dissented in International Harvester; he and Mr. Justice Brandeis concurred separately in Cohen and in Weeds, Inc. v. United States, 255 U.S. 109 (1921); Brandeis and Mr. Justice Holmes concurred separately in Connally; and in Levy Leasing, where New York's rent control legislation, N.Y. Sess. Iaws 1920, ch. 944, \$1, was found sufficiently definite, Mr. Justice McReynolds and Mr. Justice Van Devanter dissented. Note, however, that Mr. Justice McKenna joined the dissent in both International Harvester and Levy Leasing.

58283 U.S. 553 (1931).

60 Fla. Laws 1929 , ch. $13700, \S 1(\mathrm{~h})$. 
applied. The Florida courts, sustaining the statute in this application held that the act encompassed all carriers for compensation,

whether such transportation for compensation is as common carriers or as carriers for particular persons under special contract; but the statute does not require private carriers to become common carriers and the provisions of the statute that are legally applicable only to common carriers are not intended to be applied to and are not applicable to . . . persons who are not common carriers, though engaged in the transportation to which the statute refers; and the provisions of the statute that are legally applicable to private carriers for compensation are capable of being effectuated, leaving the provisions that are legally applicable only to common carriers to be applied to such common carriers as are governed by the statute. ${ }^{61}$

The statute on its face, however, made no distinction between classes of persons subject to it as regards their responsibilities under its various provisions; manifestly it had been intended to apply in its full scope to all carriers for compensation. Nor did the Florida court in its opinion detail which of the act's sections were "legally applicable" to which classes of truckers; they held only that licensing, at least, applied to Smith and left other applications to be worked out from time to time, apparently as the then prevailing pressures of substantive due process might dictate. The Supreme Court reversed on void-for-vagueness grounds. It held, first, that any attempt to apply the whole of the regulatory statute (and, in particular, the rate-fixing provisions) to noncommon carriers-a business not affected with the public interest-would be constitutionally impermissible. And second, while the Florida court's delimiting construction might save the act from this substantive due process infirmity, that construction left the scheme unenforceably indefinite:

Either the statute imposed upon the appellant obligations to which the State had no constitutional authority to subject him, or it failed to define such obligations as the State had the right to impose with the fair degree of certainty which is required of criminal statutes. Considered as severable, the statute prescribed for private carriers 'no standard of conduct that it was possible to know.' . . . The legislature could not thus impose upon laymen, at the peril of criminal prosecution, the duty of severing the statutory provisions and of thus resolving important constitutional questions with respect to the scope of a field of regulations as to which even courts are not yet in accord. ${ }^{62}$

With Smith v. Cahoon it is profitable to compare the process of litigation in Herndon v. Lowry. ${ }^{63}$ Defendant was convicted under one provi-

61 Cahoon v. Smith, 99 Fla. 1174, 1180, 128 So. 632, 634 (1930), rev'd, 283 U.S. 553 (1931)

62283 U.S. at 564.

63301 U.S. 242 (1937). 
sion of a Georgia insurrection statute making unlawful "any attempt, by persuasion or otherwise, to induce others to join in any combined resistance to the lawful authority of the state." ${ }^{81}$ The Georgia courts had read into this "inducement" section the requirement contained in another provision of the statute ${ }^{65}$ that the actor must intend that "resistance" be manifested by acts of physical force, and the judge at Herndon's trial charged the jury that to convict they must find that defendant expected to inspire "immediate serious violence." 66 Appealing on the ground, inter alia, that the evidence was insufficient to allow such a finding, the convicted defendant was met in the Georgia Supreme Court by a less stringent interpretation of the force requirement: the act made inducement punishable, that court held, if future violence might have been expected to ensue "at any time." ${ }^{87}$ Herndon was quick to petition for rehearing, arguing a violation of first amendment clear and present danger standards. Denying the petition, the Georgia court in a second opinion announced that "at any time" certainly did not mean "at any time":

[T] he phrase 'at any time' was necessarily intended, and should have been understood, to mean within a reasonable time; that is, within such time as one's persuasion or other adopted means might reasonably be expected to be directly operative in causing an insurrection. ${ }^{68}$

Here again the Supreme Court of the United States reversed, talking the language of uncertainty:

The act does not prohibit incitement to violent interference with any given activity or operation of the state. By force of it, as construed, the judge and jury trying an alleged offender cannot appraise the circumstances and character of the defendant's utterances or activities as begetting a clear and present danger of forcible obstruction of a particular state function. . . .

. . If, by the exercise of prophecy, he can forecast that, as a result of a chain of causation, following his proposed action a group may arise at some future date which will resort to force, he is bound to make the prophecy and abstain, under pain of punishment, possibly of execution. . . . The law, as thus construed, licenses the jury to create its own standard in each case. . . .

. - No reasonably ascertainable standard of guilt is prescribed. So vague and indeterminate are the boundaries thus set to the freedom

6. Ga. Acts 1866, art. 214, § 2 .

$65 \mathrm{Ga}$. Acts 1866, art. 214, §1.

${ }^{66}$ See Herndon v. State, 179 Ga. 597, 176 S.E. 620 (1934), appeal dismissed sub nom. Herndon v. Georgia, 295 U.S. 441 (1935).

67 Herndon v. State, 178 Ga. 832, 855, 174 S.E. 597, 610 (1934), appeal dismissed sub nom. Herndon v. Georgia, 295 Ú.S. 441 (1935).

68 Ferndon v. State, 179 Ga. 597, 600, 176 S.E. 620, 622 (1934), appeal dismissed sub nom. Herndon v. Georgia, 295 U.S. 441 (1935). 
of speech and assembly that the law necessarily violates the guarantees of liberty embodied in the Fourteenth Amendment. ${ }^{69}$

The dialectic in both cases is similar. ${ }^{70}$ The state legislative power has been extended to intrude upon areas forbidden by the guarantees of individual liberty of the Bill of Rights. Challenged, the state courts have withdrawn, but only as far as the unclear line of absolute constitutional prohibition itself. That withdrawal does not leave tolerance sufficient to satisfy the Supreme Court. In both cases, of course, there is the lack of fair warning. In both there is the danger that the state will get away with more inhibitory regulation than it has a constitutional right to impose, because persons at the fringes of amenability to regulation will rather obey than run the risk of erroneous constitutional judgment. But there are other vices of vagueness. Federal review of the functioning of state judges and juries in the administration of criminal and regulatory legislation is seriously obstructed by statutory unclarity. Prejudiced, discriminatory, or overreaching exercises of state authority ${ }^{71}$ may remain concealed beneath findings of fact impossible for the Court to redetermine when such sweeping statutes have been applied to the complex, contested fact constellations of particular cases." Even the "legal" component of the constitutional judgment is rendered difficult where state legislatures have failed to say what they want in precise categories of cases, so that the balance between individual freedom and the needs of the state-whatever and

69301 U.S. at 261-64.

70 Compare United States v. CIO, 335 U.S. 106, 153 (1948) (Rutledge, Black, Douglas, Murphy, JJ., concurring).

71 See Niemotko v. Maryland, 340 U.S. 268 (1951), and Hague v. CIO, 307 U.S. 496 (1939), where discriminatory enforcement was in fact found. $C f$. Thornhill v. Alabama, 310 U.S. 88, 97-98 (1940).

72 Review by the Supreme Court of the factual basis of a finding of unconstitutional confiscation in the economic legislation cases was a near impossibility even when the legal issues were relatively sharply framed. See St. Joseph Stock Yards Co. v. United States, 298 U.S. 38, 86-92 (1936) (Brandeis, J., dissenting). Difficulties of a different but equally serious nature are presented by an attempt to redetermine, on the cold record, the precise events which surrounded and are claimed to have justified an exertion of governmental force impinging on individual first amendment liberties. See Feiner v. New York, 340 U.S. 315 (1951), where the Court in effect abnegated its power to make an independent factual redetermination of findings "approved by the trial court and later by two courts on review." Id. at 619. The Court has traditionally said that in review of state criminal convictions assailed as deprivative of federal rights, it will inquire no further than the undisputed portions of the record, treating all conflicts in evidence as conclusively resolved below. E.g., Thomas v. Arizona, 356 U.S. 390, 393 (1958). This self-limitation does not, of course, impair the Court's power to re-examine secondary inferences drawn upon basic facts. See Fiske v. Kansas, 274 U.S. 380 (1927). And in any event, it does not seem that the Court has always been scrupulous in observing it in all its supposed rigor. See Moore v. Michigan, 355 U.S. 155 (1957). But it remains true that statutory standards which by reason of indefiniteness fail to provide crisp legal framing of factual issues leave the Court in a virtually impossible pose. See Herndon v. Lowry, 301 U.S. 242, 263 (1937); Joseph Burstyn, Inc. v. Wilson, 343 U.S. 495, 532 (1952) (Frankfurter, J., concurring). See also the discussions of review of questions of fact in two somewhat different contexts in Mishkin, The Federal "Question" in the District Coutrts, 53 Colum. L. Rev. 157, 172-73 (1953); Reitz, Federal Habeas Corpus: Postconviction Remedy for State Prisoners, 108 U. PA. L. REv. 461, 498, 507-12 (1960). 
however important these needs may be-must be struck without the enlightening support of a responsible a priori determination by the representatives of the community will. ${ }^{33}$ It is scarcely consonant with ordered liberty that the amenability of an individual to punishment should be judged solely upon the sum total of badness or detriment to the legitimate interests of the state which can be found, or inferred, from a backward looking appraisal of his trial record. ${ }^{4}$ In this regard attempts of the legislative authority to pass to the courts-and ultimately to the Supreme Courtthe awesome task of making case by case at once the criminal and the constitutional law understandably meet substantial judicial opposition. ${ }^{75}$

These considerations will suggest that the void-for-vagueness doctrine may be regarded less as a principle regulating the permissible relationship between written law and the potential offender than as a practical instrument mediating between, on the one hand, all of the organs of public coercion of a state and, on the other, the institution of federal protection of the individual's private interests. The doctrine determines, in effect, to what extent the administration of public order can assume a form which, first, makes possible the deprivation sub silentio of the rights of particular citizens and, second, makes virtually inefficacious the federal judicial machinery established for the vindication of those rights.

This thesis, if acceptable, has the advantage of admitting that the Court has known what it was doing (and has not been misled by a similarity of words into a confusion of concepts) when it has chosen to employ the same vagueness language in the two distinguishable classes of cases represented

73 See Sweezy v. New Hampshire, 354 U.S. 234, 254 (1957) ; Watkins v. United States, 354 U.S. 178, 205-06 (1957) ; Cantwell v. Connecticut, 310 U.S. 296, 307-08 (1940). Compare this line of reasoning with that of Gitlow v. New York, 268 U.S. $652,670-71$ (1925), refusing to apply the "clear and present danger" standard of first amendment free speech in a case where the legislature had specifically made criminal a defined class of speech. See N.Y. PEN. LAws \$\$160-61.

$74 \mathrm{~A}$ state could probably justify punishing most conduct which it desired to punish on the basis of the after-the-fact record, by isolating from the precisely detailed circumstances of the particular defendant's acts a sufficient quantum of substantive evil of legitimate legislative concern to dress up a tolerable constitutional crime. Consider the posture of the court which was asked to pass upon the validity, as against a vagueness contention, of defendant trucker's conviction for violation of an ICC regulation, 49 C.F.R. $\$ 197.1$ (b) (1949), requiring carriers of explosives to avoid congested areas "so far as practicable." Boyce Motor Lines, Inc. v. United States, 342 U.S. 337 (1952). The Government's indictment charged that defendant's truck had exploded in the Holland Tunnel and injured sixty people. See, similarly, Cole v. Arkansas, 338 U.S. 345 (1949); Screws v. United States, 325 U.S. 91 (1945). In none of these cases did the Court find the statutes vague, as in none of them had the judges and juries below been hard pressed in finding the defendants' conduct within the prohibition. Such instances may suggest the wisdom of the rule of larger caution laid down by the Court in Thornhill v. Alabama, 310 U.S. 88, 98 (1940): "An accused, after arrest and conviction under such a statute, does not have to sustain the burden of demonstrating that the state could not constitutionally have written a different and specific statute covering his activities as disclosed by the charge and the evidence introduced against him."

75 Compare the consistent, tenacious insistence of the Court, in a line of federal statute cases, that "this is no part of our duty." United States v. Reese, 92 U.S. 214, 221 (1875); Trade-Mark Cases, 100 U.S. 82 (1879); James v. Bowman, 190 U.S. 127 (1903); Yu Cong Eng v. Trinidad, 271 U.S. 500 (1926). 
by Cohen (economic regulation) ${ }^{76}$ and Winters (free speech), ${ }^{77}$ and in these two classes of cases (involving immediately penal legislation) and the Burstyn (administrative delegation) class. $^{78}$ It would help to explain, moreover, several aspects of the cases not explicable by the "fair warning" rationale ${ }^{79}$ alone: why vagueness attacks upon state legislation have in

76 See cases cited note 38 supra.

77 Watkins v. United States, 354 U.S. 178 (1957) ; United States v. Harriss, 347 U.S. 612 (1954) ; United States v. CIO, 335 U.S. 106 (1948) ; Winters v. New York, 333 U.S. 507 (1948); Cantwell v. Connecticut, 310 U.S. 296 (1940) (second count); Thornhill v. Alabama, 310 U.S. 88 (1940) ; Herndon v. Lowry, 301 U.S. 242 (1937); Stromberg v. California, 283 U.S. 359 (1931).

78 Staub v. City of Baxley, 355 U.S. 313 (1958) ; Joseph Burstyn, Inc. v. Wilson, 343 U.S. 495 (1952) ; Kunz v. New York, 340 U.S. 290 (1951) ; Largent v. Texas, 318 U.S. 418 (1943); Jones v. Opelika, 316 U.S. 584, 600 (1942) (Stone, J., dissenting), vacated per curiam, 319 U.S. 103 (1943) (adopting Mr. Justice Stone's previous dissent) ; Cantwell v. Connecticut, 310 U.S. 296 (1940) (first count) ; Lovell v. City of Griffin, 303 U.S. 444 (1938). See also the Court's per curiam decisions in Superior Films, Inc. v. Department of Educ., 346 U.S. 587 (1954), reversing 159 Ohio St. 315, 112 N.E.2d 311 (1953), and Commercial Pictures Corp. v. Regents of Univ. of N.Y., 305 N.Y. 336, 113 N.E.2d 502 (1953); Gelling v. Texas, 343 U.S. 960, reversing Gelling v. State, 157 Tex. Crim. 516, 247 S.W.2d 95 (1952). Cf. Yick Wo v. Hopkins, 118 U.S. 356, 366-67, 370 (1886). The theory of these cases was that a "license requirement constituted a prior restraint on freedom of speech . . . and, in the absence of narrowly drawn, reasonable and definite standards for the officials to follow, must be invalid." Niemotko v. Maryland, 340 U.S. 268, 271 (1951). But where the state regulatory statute was read by the state courts as conferring upon administrative or executive officers a licensing function only as a matter of "ministerial, police routine," Poulos v. New Hampshire, 345 U.S. 395, 403 (1953), to be strictly supervised by the courts to insure "uniformity of method of treatment upon the facts of each application, free from improper ... considerations and from unfair discrimination," State v. Derrickson, 97 N.H. 91, 93, 81 A.2d 312, 313 (1951), the statute was sustained. Poulos v. New Hampshire, sipra; Cox v. New Hampshire, 312 U.S. 569 (1941). Compare Breard v. Alexandria, 341 U.S. 622 (1951), with the Schneider case in Schneider v. State, 308 U.S. 141 (1939). Compare Konacs v. Cooper, 336 U.S. 77 (1949), with Saia v. New York, 334 U.S. 558 (1948). That the state courts have taken affirmative action rigorously to delimit administrative discretion and thus present for the Supreme Court record a "narrow" as opposed to "broad" or "indefinite" grant of official discretion seems a crucial factor in the Court's treatment of the cases. Compare Poulos, where the Court sustained the face validity of an ordinance after the state courts had held executive enforcement of it arbitrary and unlawful and had indicated that a license which had been refused should be granted, with Cantwell v. Connecticut, 310 U.S. 296 (1940), in which the state argued before the Supreme Court that under Connecticut law administrative orders would be subject to stringent judicial review, but where the Connecticut courts had as yet demonstrated no particular instance of such review in the case of the statute in question. The Cantwell statute was voided. Note also that the ordinance stricken down by the Court in Hague v. CIO, 307 U.S. 496, 502 (1939), contained on its face more stringent limitations upon administrative discretion ("provided, however, that said permit shall only be refused for the purpose of preventing riots, disturbances or disorderly assemblage," Jersey City, N.J., Ordinance of April 15, 1930, § 3 ) than those which the state courts had read into the New Hampshire statute, N.H. REv. Stat. AnN. \$§286.2-.3 (1955), sustained in State v. Cox, 91 N.H. 137, 143, 16 A.2d 508, 513 (1940), aff'd sub nom. Cox v. New Hampshire, 312 U.S. 569 (1941) : A systematic, consistent and just order of treatment, with reference to the convenience of public use of the highways, is the statutory mandate." But in Hague the case came to the Court by route of a federal district court suit to enjoin enforcement of the ordinance, and the state courts had as yet had no opportunity to prove their supervisory vigilance.

79 At least since the time of John Chipman Gray's pronouncement that "practically, in its application to actual affairs, for most of the laity, the Law . . . is all ex post facto," Gray, The Nature and Sources of Law 100 (1921), it has been the fashion of legal scholars to attack the notion that, except in a few special areas (as, for example, taxes, securities issuance, conveyances), anyone actually relies on the 
general been far more successful than vagueness attacks upon federal legislation (over whose enforcement the Supreme Court has considerably more flexible powers of control) ${ }^{80}$ why the Court should be more concerned

state of the law at the time he acts. A sufficient debunking of this notion would, of course, undercut the fair warning rationale altogether. Yet it is obvious that this rationale has had a certain persisting, vital (if not exclusive) impact on the vagueness cases, and fair warning notions have been crucial in other contiguous areas. See Lambert v. California, 355 U.S. 225 (1957). In the administration of criminal law, at least, the Court still seems to hold, as did Mr. Justice Holmes, that "although it is not likely that a criminal will carefully consider the text of the law before he murders or steals, it is reasonable that a fair warning should be given to the world in language that the common world will understand of what the law intends to do if a certain line is passed." McBoyle v. United States, 283 U.S. 25, 27 (1931). It is not the attempt of this Note, in stressing that pressures other than fair warning are operative in the void-for-vagueness doctrine, to depreciate the booby trap problem. The effort here is only to delineate the extent to which the vagueness cases have been moved by other considerations-an effort which seems necessary both from the standpoint of predicting what the Court will in fact do with a given case, and in order to assure that, in situations where warning does not present a problem but where those other considerations do, the precedent of the vagueness line is not mistakenly rejected upon erroneous application of ratio cessante reasoning. See notes 89-103 infra and accompanying text.

80 Except for $\$ 4$ of the Lever Act involved in Cohen, its companions, and Small, see notes 11 and 14 supra and accompanying text, no federal statute has ever been declared unconstitutional for vagueness. United States v. Korpan, 354 U.S. 271 (1957); United States v. Kahriger, 345 U.S. 22 (1953) ; United States v. Spector, 343 U.S. 169 (1952) ; Dennis v. United States, 341 U.S. 494 (1951) ; Jordar v. De George, 341 U.S. 223 (1951); Williams v. United States, 341 U.S. 97 (1951); American Communications Ass'n v. Douds, 339 U.S. 382 (1950); United States v. CIO, 335 U.S. 106 (1948); United States v. Petrillo, 332 U.S. 1 (1947); Screws v. United States, 325 U.S. 91 (1945) ; United States v. Ragen, 314 U.S. 512 (1942); United States v. Darby, 312 U.S. 100 (1941); Gorin v. United States, 312 U.S. 19 (1941) ; Shields v. Utah I. Cent. R.R., 305 U.S. 177 (1938); Kay v. United States, 303 U.S. 1 (1938); United States v. Wurzbach, 280 U.S. 396 (1930); United States v. Alford, 274 U.S. 264 (1927) ; Baltimore \& O.R.R. v. Groeger, 266 U.S. 521 (1925) ; Mahler v. Eby, 264 U.S. 32 (1924); Nash v. United States, 229 U.S. 373 (1913); Ex parte Webb, 225 U.S. 663 (1912). Cf. FTC v. Ruberoid Co., 343 U.S. 470 (1952) (administrative orders) ; Boyce Motor Lines, Inc. v. United States, 342 U.S. 337 (1952). In general the Court seems to have relied upon its own power to construe federal statutes and to supervise their administration, a power which it has continuously used to delimit congressional legislation sought to be too sweepingly applied. See cases cited notes 94-97 infra. Only under the extraordinary fact situation of Watkins v. United States, 354 U.S. 178 (1957), has it resorted to constitutional grounds, and here it was to invalidate only the particular application of a statute otherwise left unimpaired, Barenblatt v. United States, 360 U.S. 109 (1959). Consider the complaint in Kunz v. New York, 340 U.S. 290, 308 (1951) (Jackson, J., dissenting): "As this case exemplifies, local acts are struck down, not because in practical application they have actually invaded anyone's protected freedoms, but because they do not set up standards which would make such an invasion impossible. However, with federal statutes, we say they must stand unless they require, or in application are shown actually to have resulted in, an invasion of a protected freedom." If the crux of the vagueness cases is the matter of the Court's control over the crucial adjustment of governmental and individual interests, the practice which Mr. Justice Jackson found unwarranted makes considerable practical sense. Not only is the Court's ultimate power to interpret and police federal statutes a ready instrument of mastery, but it must be remembered that federal statutes will come under adjudication by the federal judiciary, presumably more sensitive to claims of federal Bill of Rights freedoms than are the states' judges. At least this is the presumption which seems in part to underlie the provisions of 28 U.S.C. $\$ 1257(2)$ (1958), allowing appeal jurisdiction in the Supreme Court of cases in which state courts have sustained state statutes against claims that they abridge federal rights. Compare 28 U.S.C. $\$ \S 1254,1257$ (1) (1958). This observation has been made in another (and more compelling) context by Mishkin, supra note 72, at 158 n.10. 
with what state courts do with a statute after the defendant has committed his offending act than how the statute might have looked to him at the time of commission; ${ }^{81}$ why legislation creating "new" crimes (which does not generically tend to be unclear, but is likely to represent affirmative legislative intrusion into realms previously left to individual freedom) is particularly vulnerable to vagueness attack. ${ }^{82}$ "Old" common-law terms may have no more illuminating clarity to the layman offender than the neologisms of Ronsard, but they do present an effective means by which one bench of judges can supervise the law administration of another. ${ }^{83}$ The thesis would also offer an explanation for the holding that state legislation which is applied so as to force persons in the exercise of their civil liberties to guess exactly the location of the line of federal protection is too vague, ${ }^{84}$ but that a federal civil rights provision which, by penalizing whoever under color of state law willfully subjects an inhabitant of any state "to the deprivation of any rights, privileges, or immunities secured or protected by the Constitution or laws of the United States," ${ }^{85}$ forces state officials to guess exactly the location of the same line, is not too vague. ${ }^{86}$ And, finally, the very pattern of incidence of the void-for-vagueness cases, first in the

81 See notes 34-37 supra and accompanying text.

82 Among cases emphasizing the "new" crime aspect in striking down statutes, see Winters v. New York, 333 U.S. 507, 519-20 (1948); Connally v. General Constr. Co., 269 U.S. 385 (1926) ; United States v. Reese, 92 U.S. 214, 219 (1875) ; United States v. Harriss, 347 U.S. 612, 634 (1954) (Jackson, J., dissenting); United States v. Petrillo, 332 U.S. 1, 16-17 (1947) (Reed, J., dissenting). The Court has employed the antiquity of statutes as a reason in favor of sustaining them. United States v. Ragen, 314 U.S. 513, 524 (1942). See also Winters v. New York, stupra at 520-22 (Frankfurter, J., dissenting). It has sustained them on their similarity to other more venerable criminal standards. Beauharnais v. Illinois, 343 U.S. 250 (1952); Fox v. Washington, 236 U.S. 273 (1915); Waters-Pierce Oil Co. v. Texas, 212 U.S. 86 (1909). For cases honoring an imported antiquity in sustaining statutes which make use of familiar common-law terms, see note 83 infra.

83 Finding clarification in the common law, see Nash v. United States, 229 U.S. 373 (1913). See also the distinction of Nash in Cline v. Frink Dairy Co., 274 U.S. 445, 460 (1927) ; Weeds, Inc. v. United States, 255 U.S. 109, 112 (1921) (Brandeis, J., concurring). Cf. Gorin v. United States, 312 U.S. 19, 28 (1941) (prior statute). Stressing lack of common-law meaning in statutes struck down, see Lanzetta v. New Jersey, 306 U.S. 451, 454-55 (1939) ; Champlin Ref. Co. v. Corporation Comm'n, 286 U.S. 210, 242-43 (1932). See also, for both sides of the coin, cases cited in note 82 supra. Is it common-law antiquity on which turns the distinction between "obscene," Roth v. United States, 354 U.S. 476 (1957), and "sacrilegious," Joseph Burstyn, Inc. v. Wilson, 343 U.S. 495 (1952)? Winters v. New York, 333 U.S. 507, 518 (1948), suggests that it may be; and consider the methodology of Mr. Justice Frankfurter's Burstyn concurrence, 343 U.S. at 495 . Certainly this discrimination is not supportable on the clarity of "obscene." See Lockhart \& McClure, Literature, the Law of Obscenity, and the Constitution, 38 MinN. L. Rev. 295, 320-24 (1954), demonstrating conclusively the polyvalence of that concept.

84 See text accompanying notes 46-51 supra, and see note 49 supra; see also text at notes $70-71$ supra.

85 Criminal Code $\$ 20,18$ U.S.C. $\$ 242$ (1958).

86 Williams v. United States, 341 U.S. 97 (1951) ; Screws v. United States, 325 U.S. 91 (1945). Attempts to import as standards of criminality others of the various fiuid "jurisdictional" lines which the judicial temper of each era must draw from the enumerations and restrictions of the federal constitution, or to overreach those lines, have also been subjected to vagueness attack. The attack succeeded in Smith $v$. 
sphere of economics at a time when economics was the sphere where the Court rode tightest rein on legislative innovation, ${ }^{87}$ and today in the now most critical field of free expression, ${ }^{88}$ tends to affirm the view that the vagueness doctrine is chiefly an instrument of buffer-zone protection.

\section{VAGUENESS AND VAgUE WARNING IN VOID-FOR-VAGUENESS}

This conclusion should not be misunderstood. It does not mean, in the first place, that unconstitutional uncertainty will never be found in a statute all of whose possible applications the enacting legislature would have had constitutional power to prescribe. It does not mean that a state, having competence to outlaw all the conduct of type $A$ and all the conduct of type $B$, may outlaw only one and yet draw the $A-B$ line as fuzzily as it will. There is no doubt that want of warning is itself a defect, and there have been cases-Lanzetta ${ }^{89}$ and perhaps Connally ${ }^{90}$-in which this element

Cahoon, 283 U.S. 553 (1931), described in text at notes 58-62 supra, where the Court regarded state regulatory legislation as indefinitely straddling the line of permissible intervention into the then recognized preserve of private economic rights. The attack did not succeed in United States v. Darby, 312 U.S. 100 (1941), where defendant argued that a federal enactment penalizing the transportation in interstate commerce of goods in the course of whose production employees "engaged in [interstate] commerce or the production of goods for [interstate] commerce," Fair Labor Standards Act of 1938, $\S 15$ (a) (1), (2), (5), 52 Stat. 1068, as amended, 29 U.S.C. $\$ \$ 215$ (a) (1), (2), (5) (1958), had been worked in violation of the minimum-wage and maximum-hour provisions of the act, was (by reason of its assimilation of the nebulous limits of the federal commerce power) unconstitutionally indefinite. The Court upheld the standard, at least as applied to a shipper-employer who had produced goods with the expectation that in the normal course of his business some or all would be shipped to out-of-state customers. Id. at 125-26. Notice that here the "jurisdictional" line which the legislation straddles is not one drawn (as are the bounds of the Bill of Rights or as were the bounds of economic freedom at the time of Sinith v. Cahoon) to strike a measure of adjustment of individual as against governmental equilibrium of the federal system. For the individual, then, the only element of harm in a statute which straddles the line is want of notice; there is no problem of possible congressional overreaching of his (as opposed to the states') interests. In such a situation it is understandable that the federal courts would be slower than in a civil liberties case to force the (in this instance federal) legislature to draw standards more distinct than the absolute boundary of its competence. To drive the individual against a wall behind which he can in any event seek no sanctuary, since it was not erected for the safeguarding of his interests, may well be allowable; indeed, the courts may regard the existence of an indistinct periphery to federal power as a significant implement to the federal program. This will be the more evident in the case of the several federal crimes which, although they do not substantively incorporate a standard dependent on the reach of the commerce power, nevertheless are predicated upon that power and thus, in their incidence, must realistically be regarded as involving much of the same uncertainty that Darby complained of. The conduct of a potential offender under such laws is not measured, theoretically, by the reaches of the enumerated federal power to regulate commerce among the states, but as a practical matter his amenability to punishment will be. See United States v. Stirone, 262 F.2d 571 (3d Cir. 1958), rev'd on other grousts, 361 U.S. 212 (1960).

87 See notes $38-39$ and 58 supra.

88 See notes $39-40$ supra.

89 Lanzetta v. New Jersey, 306 U.S. 451 (1939), construing N.J. Laws 1934, ch. $155, \S 4$.

90 Connally v. General Constr. Co., 269 U.S. 385 (1926), construing Okla. Laws 1909 , ch. 39, at 635 . 
alone has seemed to account for the invalidation of enactments ${ }^{91}$ or, in the case of federal statutes, the Court's simple refusal to enforce them.92 Even more significant, in the federal area, is the force of a perceived uncertainty, and consequent lack of fair notice, upon the construction-as opposed to the outright invalidation - of statutes. ${ }^{93}$ Where a contention of vagueness is advanced with regard to federal legislation, of course, the Court may narrowly interpret the act ${ }^{94}$ (and, as so interpreted, either apply it ${ }^{95}$ or not apply it ${ }^{96}$ to the defendant in the case at bar) rather than void it, and there has been a significant tendency to adopt this narrowing, rather than annihilating, course. ${ }^{97}$ It is clear that the counsel who seeks reversal of a federal conviction will have taken a significant step toward success if he can convince the Court that in its application to his client a statute presents the appearance of a booby trap. And, where conviction is under a state statute or where his client's case is within even the most restricted tenable

91 Ingenuity might labor to produce a "confiscation" argument in Comally and perhaps a "freedom of association" argument in Lanzetta. But it seems more probable to attribute these holdings to what their opinions say they are concerned with: lack of notice.

92 See United States v. Cardiff, 344 U.S. 174 (1952) (act too uncertain, no constitutional ground involved). For a case involving a statute found so unclear as to be unenforceable, despite no want of adequate warning, see United States v. Evans, 333 U.S. 483 (1948). See note 2 supra for reference to the theory that this commonlaw sort of refusal to enforce is the root of the constitutional void-for-vagueness doctrine.

83 This is, of course, a procedure in which the Court cannot indulge with regard to state statutes. But see the astounding (to the modern eye) opinion in Fox v. Washington, 236 U.S. 273 (1915), in which, under the guise of a presumption as to how the state courts would construe their state's statute, the Court in fact construed it and sustained it as construed.

84 Dennis v. United States, 341 U.S. 494, 502 (1951) (federal conviction sustained against first amendment and vagueness claims): "This is a federal statute which we nust interpret as well as judge. Herein lies the fallacy of reliance upon the manner in which this Court has treated judgments of state courts. Where the statute as construed by the state courts transgressed the First Amendment, we could not but invalidate the judgments of conviction."

95 E.g., Kay v. United States, 303 U.S. 1 (1938); United States v. Shreveport Grain \& Elevator Co., 287 U.S. 77 (1932).

${ }^{96}$ E.g., Pierce v. United States, 314 U.S. 306 (1941); McBoyle v. United States, 283 U.S. 25 (1931); cf. United States v. Brewer, 139 U.S. 278 (1891) (interpreting state law for purposes of federal criminal law). For an analogous civil case, see United States v. Pennsylvania R.R., 242 U.S. 208 (1916). Compare United States v. Rumely, 345 U.S. 41 (1953). On occasion, however, the Court has chosen the wider of two possible interpretations, in such a fashion as perhaps seriously to have trapped the defendant before it. See, e.g., Gorin v. United States, 312 U.S. 19 (1941); United States v. Alford, 274 U.S. 264 (1927).

97 Screws v. United States, 325 U.S. 91 (1945): "This Court has consistently favored that interpretation of legislation which supports its constitutionality." Id. at 98. "Only if no construction can save the Act from this claim of unconstitutionality are we willing to reach that result." Id. at 100 . The same course has been taken in several cases of uncertainty with possible first amendment overreach, and from these decisions especially have emerged statutes seemingly very different from anything Congress enacted. See United States v. Harriss, 347 U.S. 612 (1954); United States v. CIO, 335 U.S. 106 (1948). In CIO the statute, Labor Management Relations Act (TaftHartley Act), ch. $120, \$ 304,61$ Stat. 159 (1947), was interpreted to exclude from coverage a case which its Senate sponsor had expressly said on the floor (in response to a hypothetical question) was included. See 93 Cong. Rec. 6437-38 (1947) (responses of Senator Taft to Senator Barkley). 
meaning of a federal act, he may perhaps succeed in invoking the invalidating rule of Lanzetta-provided that his client's conduct is not particularly evil as viewed by the prevailing moral temper of the Court, ${ }^{88}$ that the ambiguity he urges is not seen by the Court as a mere pretext for evasion, ${ }^{99}$ and that other, clearer legislative methods of achieving the end sought by the contested statute appear to the Court possible and equally practicable. ${ }^{100}$

Second, recognition that the vagueness doctrine is most frequently employed as an implement for curbing legislative invasion of constitutional

98 It seems significant that the void-for-vagueness doctrine has been successfully invoked before the Court only by convicted or putative offenders against the economic regulatory laws - white collar crime, not malum in se-or against various crimes of speech, those American crossbreeds between the nuisance and the political crime. Of course this correlation may be explicable in terms of other elements of these crimes than the moral one: they do involve the areas where as a matter of history constitutional safeguards of individual freedom have been important; they are liable to constitute "new" crimes, responsible to modern economic and political stresses, employing words for their articulation for which the courts can find no common-law precedent; and, finally, they are perhaps those crimes as to which possible offenders are most likely to study the statute books in advance and actually rely on the law. But beyond these explanations there seems to have been a persisting tendency on the Court to look to ethical overtones in vagueness situations. See Hygrade Provision Co. v. Sherman, 266 U.S. 497 (1925); Miller v. Strahl, 239 U.S. 426 (1915); United States v. Harriss, 347 U.S. 612, 633 (1954) (Jackson, J., dissenting); and compare Dennis v. United States, 341 U.S. 494,515 (1951) (quoted in text at note 184 infra); Williams v. United States, 341 U.S. 97 (1951). This same conception is instinct in the theme of "scienter" or mens rea which runs through the vagueness cases. "Scienter" has frequently been found a component of the offense created by the statute charged with indefiniteness, and on each occasion the statute has been sustained, in part on the notion that the requirement of guilty knowledge clarified it. Boyce Motor Lines, Inc. v. United States, 342 U.S. 337 (1952); American Communications Ass'n v. Douds, 339 U.S. 382 (1950) ; Screws v. United States, 325 U.S. 91 (1945); United States v. Ragen, 314 U.S. 513 (1942); Gorin v. United States, 312 U.S. 19 (1941) ; Omaechevarria v. Idaho, 246 U.S. 343 (1918). Yet it is evident that, unless the Court has been fooling itself in these cases, the "scienter" meant must be some other kind of scienter than that traditionally known to the common law-the knowing performance of an act with intent to bring about that thing, whatever it is, which the statute proscribes, knowledge of the fact that it is so proscribed being immaterial. Ellis v. United States, 206 U.S. 246, 257 (1907). Such scienter would clarify nothing; a clarificatory "scienter" must envisage not only a knowing what is done but a knowing that what is done is unlawful or, at least, so "wrong" that it is probably unlawful. One difficulty here is that it is uncertain whether the courts which subsequently enforce the statutes which the Court sustains will employ the same brand of "scienter" as the Court; if not, and if "scienter" was essential to the Court's holding, then of course the statute which is constitutional is not being administered and the statute which is being administered is not constitutional. In any event, "scienter" has become a recognized element of the lore of vagueness, and represents at its best, a tool to be designedly used in the service of other ends; at its worst, a port of entry for the ethical predilections of the then sitting Court.

99 Although the Court has not couched its opinions in terms of evasion, as might be expected its decisions show a marked consistency in finding statutes definite enough where it appears that the individual who is crying "vague" must have known of the statute, must have perceived its ambiguity, might (without much inconvenience) have done something which would have made clear in his particular case the statute's meaning or which would have constituted compliance with the statute under any meaning, but instead chose to exploit the ambiguity to his own advantage. United States v. Korpan, 354 U.S. 271 (1957) ; United States v. Five Gambling Devices, 346 U.S. 441 (1953); United States v. Kahriger, 345 U.S. 22 (1953); United States v. Ragen, 314 U.S. 513 (1942); Hygrade Provision Co. v. Sherman, 266 U.S. 497 (1925).

100 Regarding the principle of necessity in the vagueness cases, see notes $150-51$ infra and accompanying text. 
rights other than that of fair notice (or whatever due process may incorporate of the maxims nulla poena sine lege and ubi jus incertum, ibi jus nullum) does not mean that the doctrine may be indiscriminately invoked to curb all such invasions, or that there is not an actual vagueness component in the vagueness decisions. Certainly a precondition to the Court's accepting an argument of uncertainty seems to be that the statute is in fact more uncertain-offering less warning to anyone who should bother to consult it, laying down fewer lines of restraint upon the caprice of juries, agencies, and judges, and permitting less sufficient delimitation of specific factual and legal issues for purposes of effective federal review-than the mine run of statutes. Vagueness is not an extraneous ploy or a judicial deus ex machina but rather has very intimate connections both with the substance of individual freedom from arbitrary and discriminatory governmental action and, as has been indicated, with the federal institutional processes established to protect that freedom. The point here is that to see in the vagueness cases merely the operation of an isolated judicial concern for fair notice-even where such a view is qualified by the addendum that, because of the threat of overreaching, "the standard of definiteness for statutes curtailing free expression is stricter than it is for other types of statutes" ${ }^{101}$ is to fail to appreciate many of the forces which have forged the doctrine and determined its shape.102 Significant among these have been intricate problems of judicial-administrative, judicial-legislative, and federal-state relationships, of individual standing to raise constitutional questions, of scope of review, and of the effect of an invalidating decision by the Court. ${ }^{103}$

101 Scott, Constitutional Limitations on Substantive Criminal Law, 29 RockY Mr. L. REv. 275, 288 (1957).

102 If the impelling force of vagueness doctrine were solely fair notice considerations, it seems certain that the doctrine would have developed in forms and subdoctrines very different from those in which it has evolved. Consider, for example, the position of the writer in Comment, 53 Mich. L. REv. 264, 270 (1954), who, having assumed a fair warning base, continues: "The basic question seems to be whether or not a person should be allowed to assert vagueness as a defense without some indication that he actually consulted the statute with a view toward compliance." And Professor Freund, who places the problem of fair notice at the pivot of his analysis, strongly takes the position that it is improper for the Court to permit a statute vague at the time of defendant's act to be cured by subsequent state court construction in defendant's own case. Freund, The Supreme Court and Civil Liberties, 4 VAND. L. REv. 533, 540-41 (1951).

103 This Note will not attempt systematically to present the several dogmas of void-for-vagueness lore-the question of how vague is too vague (the "men of common intelligence must necessarily guess" test, Connally v. General Constr. Co., 269 U.S. 385,391 (1926), and the "so empty of meaning that no one desirous of obeying the law could fairly be aware" test, Winters v. New York, 333 U.S. 507, 524 (1948)); the saw that terms with a common-law meaning are sufficiently definite; that administered statutes need be less clear than self-enforcing ones, and civil less clear than criminal; the effects of scienter, of state court construction, of the nature of the subject matter, and so on. Many of these matters have been treated in footnotes above, although from a perspective which has stressed their symptomatic rather than their doctrinal significance, and very adequate discussion and analysis of the vagueness dogmas will be found in the commentators cited in notes 2 and 3 supra. For perhaps the best articulation of the relevant considerations in any given case, see Winters v. New York, 333 U.S. 507, 525 (1948) (Frankfurter, J., dissenting). 


\section{The Doctrine From the Aspect of Federal Judicial Control}

Underlying all of these pressures is that conception of the Supreme Court which shaped its decision, announced in Marbury v. Madison ${ }^{104}$ and Martin v. Hunter's Lessee, ${ }^{105}$ to assume the power of ultimate constitutional review : that the high Court should stand, under the Constitution, as the final arbiter between the competing wills and needs of the whole people (represented in its legislatures) and of the individual. ${ }^{108}$ This role, within a system which posits the supremacy of fundamental written law, ${ }^{107}$ requires at the least a continued surveillance to assure the regularity of legislated and administered modes of applying public compulsion to all particular men. ${ }^{108}$ It requires, as a corollary, the maintenance of a state of institutions in which that surveillance is kept effective. ${ }^{109}$ Because of the Court's limited power to reexamine fact on a cold record, ${ }^{110}$ what appears to be going on in the administration of the law must be forced, by restrictive procedures, to reflect what is really going on; and because of the impossibility, through sheer volume of cases, of the Court's effectively policing law administration case by case, those procedures must be framed to assure, as well as procedures can assure, a certain overall probability of regularity. ${ }^{111}$ But if the system is to remain viable, the restriction of procedures in the service of regularity must not be so rigorous as to prevent the national and state legislatures from effectuating a substantive end not constitutionally denied them, by whatever permissible means those bodies consider most appropriate.112

10455 U.S. (1 Cranch) 137 (1803).

10514 U.S. (1 Wheat.) 303 (1816).

106 This role seems to have been understood by the Constitutional Convention, which several times rejected the proposal that the national judiciary be associated with the legislative process, in part on the reasoning that "the Judges ought to be able to expound the law as it should come before them, free from the bias of having participated in its formation." 1 FARRAND, THE Rerords OF THE FEDERAL CoNvention of 1787, at 98 (1911) (Mr. King, June 4). As regards federal judicial review of state legislation, see Tre FEDERALIST, No. 80 (Hamilton).

107 See Hart \& Wechsler, The Federal Courts and the Federal System 333-34 (1953).

108 "[T] he very idea that one man may be compelled to hold his life, or the means of living, or any material right essential to the enjoyment of life, at the mere will of another, seems to be intolerable in any country where freedom prevails, as being the essence of slavery itself." Yick Wo v. Hopkins, 118 U.S. 356, 370 (1886).

109 See e.g., Young v. Ragen, 337 U.S. 235 (1949); Ward v. Love County, 253 U.S. 17 (1920).

110 See note 72 supra. Concerning the poor quality of the records available to the Court on review of state criminal convictions, see Reitz, supra note 72 , at 474-75, 497-500, 507-10.

111 See Niemotko v. Maryland, 340 U.S. 268, 285 (1951) (Frankfurter, J., concurring): "The vice to be guarded against is arbitrary action by officials. "The fact that in a particular instance an action appears not arbitrary does not save the validity of the authority under which the action was taken."

112 The principle of a wide legislative discretion both in the national Congress and in the representative assemblies of the states has become a cardinal tenet of federal constitutional law. As to Congress, see, e.g., Yakus v. United States, 321 U.S. 414 (1944); United States v. Carolene Prods. Co., 304 U.S. 144 (1938). And, as to the states, see, e.g., Wolf v. Colorado, 338 U.S. 25 (1949); New State Ice Co. v. Liebmann, 
One basic need in adjusting conflicting public and individual interests is to assure responsible control over the scope and probable regularity of exercise of governmental force. Under a system of legislated, published laws, that scope and probable regularity will be mediated by words; and void-for-vagueness theory purports explicitly to regulate the permissible degree of ductility of words. The common fault of the too incomprehensible statute in Lanzetta, ${ }^{113}$ the too approximative statute in Cline, ${ }^{114}$ and the too discretion-giving statute in Gelling ${ }^{115}$ is that each injects into the governmental wheel so much free play that in the practical course of its operation it is likely to function erratically-responsive to whim or discrimination unrelated to any specific determination of need by the responsible policy-making organs of society-and to result in a significant number of impermissible public-versus-private-interest resolutions which are beyond the effective discovery or appraisal of the Court. ${ }^{118}$

Of course, all words are ductile to some extent. ${ }^{117}$ But there are different ways in which a statutory phrase may bear the possibility of vagaries, and each category possesses its own degree of danger for the orderly administration of law. Professor Freund has distinguished "three grades of certainty in the language of statutes of general operation: precisely measured terms, abstractions of common certainty, and terms involving an appeal to judgment or a question of degree." 118 For purposes of analysis of the vagueness problem, the "precisely measured" grade ${ }^{119}$ may be put aside (such terms are never found in the vagueness cases-and probably

285 U.S. 262, 280 (1932) (Brandeis, J., dissenting). A significant expression of federal judicial deference to the lawmaking organs of the states in the formulation of state governmental policy and the adjustment of that policy to the federal civil rights of individuals, at least in the first instance, may be witnessed in the progressive development of the abstention doctrine of Railroad Comm'n v. Pullman Co., 312 U.S. 496 (1941), discussed at length in Note, Abstention: An Exercise in Federalism, $108 \mathrm{U}$. PA. L. REv. 226 (1959).

113 Lanzetta v. New Jersey, 306 U.S. 451 (1939), construing N.J. Laws 1934, ch. 155, \&4 (making an element of the crime being "known to be a member of any gang consisting of two or more persons").

114 Cline v. Frink Dairy Co., 274 U.S. 445 (1927), construing Colo. Acts 1913, ch. 161 (banning combinations in restraint of trade except those intended to market at a "reasonable price" products which could not otherwise be so marketed).

115 Gelling v. Texas, 343 U.S. 960 (1952) (per curiam). This case involved a municipal ordinance which provided that the board of censors should deny a license for the showing of any films which the board was of the opinion were "of such a character as to be prejudicial to the best interests of the people. . . ."

116 Cf. Cantwell v. Connecticut, 310 U.S. 296, 307-08 (1940) ; Herndon v. Lowry, 301 U.S. 242, 261-64 (1937).

117 See Frankfurter, Some Reflections on the Reading of Statutes, 47 Colum. L. REv. 527, 528 (1947). The thrust of modern writing on semantics has been largely cautionary-intent on pointing out the traps and mystifications inherent in the polyvalent nature of language. Most significant have been KoRzYBSKI, ScIENCE AND Sanity (4th ed. 1958); Ogden \& Richards, The Meaning of Meaning (5th ed. 1938).

118 Freund, The Use of Indefinite Terms in Statutes, 30 YALE L.J. 437 (1921). 119 This grade has found perhaps its most successful employment in taxing statutes, e.g., INT. REv. CODE OF 1954, §§ 1, 3, and in administrative regulations under the various regulatory schemes, e.g., the Department of Agriculture's standards for fresh fruits, etc., found in 7 C.F.R. pt. 51 (1959): 
very seldom in the statute books) $;^{120}$ the distinction between the second and third classes is the significant one. In rough, it corresponds to the distinction drawn by the semanticists between verbal symbols having an external object-referent and verbal symbols having no such referent. ${ }^{121}$

Words which refer to ascertainable objects or relations may be ambiguous; it may be impossible to say to which of several objects they refer. This is the case of the two ships "Peerless"; ${ }^{122}$ and where the ambivalent word is in a criminal statute, there may exist a very real menace of mousetrapping. Yet the Court has not struck down such statutes. ${ }^{123}$ In terms of the control-by-the-Court analysis suggested above, this is understandable, inasmuch as words which have merely an initial ambiguity, however they may fail to warn the initial offender, pose little problem of continuing irregularity in the course of administration. What these words need is a pointing definition-a direction which attaches them to that one object to which they refer-and once their definition is supplied, they bode no future ill. United States $v$. Alford, ${ }^{124}$ for instance, involved a federal

120 See Perkeis, Law and Social Acrion 5 (1950); Freund, sipra note 118, at 437. There probably exists a considerable number of outstanding statutes which, by any standard which the Court has yet articulated, are void for vagueness. Consider, for example, Edelman v. California, 344 U.S. 357 (1953), where defendant had been convicted under CAL. PEN. CoDE §647(5): "Every idle, or lewd, or dissolute person, or associate of known thieves is a vagrant and is punishable ...." Defendant had failed to raise seasonably the vagueness point and the Court did not consider it. The judge at Edelman's trial had charged: "Vagrancy is a continuing offense. It differs from most other offenses in the fact that it is chronic rather than acute; that it continues after it is complete and subjects the offender to arrest at any time before he reforms. One is guilty of being a vagrant at any time and place where he is found, so long as his character remains unchanged, although then and there innocent of any act demonstrating his character. . . His character ... is the ultimate question for you to decide . . . Now dissolute is defined as "loosed from restraint, unashamed, lawless, loose in morals and conduct, recklessly abandoned to sensual pleasures, profligate, wanton, lewd, debauched." Now the word, "dissolute," as you see from this definition, covers many acts not necessarily confined to immorality. Other laxness and looseness and lawlessness may account to dissoluteness.' " 344 U.S. at 365 (dissenting opinion). It may be suggested that Edelman represents in a single disquieting image all of the evils which justify the constitutional void-for-vagueness doctrine. Here is the coercive force of society run loose at the whim of prosecutor and jury, without adequate restraint at the level of the trial court (for want of standards by which to restrain), enforced against indigent and unrepresented defendants unable to assure in their own defense the adequate preservation of a trial record or the rulings of the court on their federal issue, unlikely-even if a federal issue should be raised-to know or be able to afford to take that issue to a federal court.

121 See the excellent study by Williams, Language and the Law (pts. 1-4), 61 L.Q. REv. 71, 179, 293, 384 (1945), (pt. 5), 62 L.Q. REv. 387 (1946).

122 Raffles v. Wichelhaus, 2 H. \& C. 906, 159 Eng. Rep. 375 (Ex. 1864).

123 E.g., United States v. Spector, 343 U.S. 169 (1952) ("travel or other documents necessary for his departure"); United States v. CIO, 335 U.S. 106 (1948) ("expenditure in connection with any election"); Minnesota ex rel. Pearson v. Probate Court, 309 U.S. 270 (1940) ("psychopathic personality"); Omaechevarria v. Idaho, 246 U.S. 343 (1918) ("range"); Ohio ex rel. Lloyd v. Dollison, 194 U.S. 445 (1904) ("wholesale"). Object-referents, of course, come in all degrees of subtlety. Compare Screws v. United States, 325 U.S. 91 (1945) ("any rights, privileges or immunities secured by the Constitution"); United States v. Darby, 312 U.S. 100 (1941) ("engaged in [interstate] commerce or the production of goods for commerce") ; Hygrade Provision Co. v. Sherman, 266 U.S. 497 (1925) ("kosher").

124274 U.S. 264 (1927). 
statute penalizing "whoever shall build a fire in or near any forest, timber, or other inflammable material upon the public domain. . . ."125 Defendant contended, inter alia, that "upon" modified "build," not "timber." The Court read "upon" as modifying "timber," and the statute as so construed was held sufficiently definite. ${ }^{126}$ Or consider Bandini Petroleum Co. v. Superior Court, ${ }^{127}$ which involved a state statute prohibiting "unreasonable waste" in natural gas production. 128 Although the "unreasonable" portion of this phrase appears to involve a referentless word, the state court read "unreasonable waste" as a unit and defined it to mean the allowing of gas to come to the surface without its lifting power having been utilized to raise an optimal proportion of oil-a standard which the court found was one which could be calculated with mathematical certainty within the physical situation of any given well. The Supreme Court affirmed a judgment that the statute was not unconstitutionally vague. It is only where a state court has several times applied such a term of external reference without at any juncture attempting to fix its object-as the application of "gang" 129 in Lanzetta-that the Court has voided the statute. ${ }^{130}$ The only other externally pointing statute which the Court has held too uncertain is that in Connally. ${ }^{131}$ But here the object-referent-the state statute involved "the current rate of per diem wages in the locality" 132 was regarded by the Court as itself inherently incapable of fixation. There would always be several such "current wages" within a "locality," the Court believed; thus the pointer remained oscillatory. ${ }^{133}$

The language which no decision can definitively clarify and which consequently has been the virtually exclusive target of void-for-vagueness nullification is that which falls within Professor Freund's third category: 372 (1958).

125 Act of June 25,1910 , ch. $431, \S 6,36$ Stat. 855 , as amended, 25 U.S.C. $\S \S 151$,

126 Defendant's alternative contention, that the statute was too uncertain even if "upon" modified "timber" (based on the indefiniteness of the word "near"), was given short shrift by Mr. Justice Holmes. Id. at 267.

127284 U.S. 8 (1931).

128 Cal. Pub. Resources Code $\S 3300$.

129 N.J. Laws 1934, ch. 155, \& 4.

130 Having considered the treatment of the statutory phrase "known to be a member of any gang" by several levels of New Jersey courts in both the case at bar and State v. Gaynor, 119 N.J.L. 582, 197 Atl. 360 (1938), the Supreme Court concluded: "The descriptions and illustrations used by the court to indicate the meaning of 'gang' are not sufficient to constitute definition, inclusive or exclusive. The court's opinion was framed to apply the statute to the offenders and accusation in the case then under consideration; it does not purport to give any interpretation generally applicable." Lanzetta v. New Jersey, 306 U.S. 451, 457 (1939). But see Minnesota ex rel. Pearson v. Probate Court, 309 U.S. 270 (1940), where the Court read a state court declaration that the allegedly vague term "included" $X, 205$ Minn. 545, 555, 287 N.W. 297, 302 (1939), as an exhaustive definition. The tenor of this Minnesota opinion does not suggest that such a reading is correct.

131 Connally v. General Constr. Co., 269 U.S. 385 (1926).

132 Okla. Laws 1909, ch. 39, at 635.

133 Connally came up on appeal from a federal district court suit to enjoin enforcement; it is likely that had the Connally statute come through the state courts as did the Bandini statute, those courts could have clarified it to the Court's satisfaction. 
terms of judgment and degree. Here are Cohen's "unreasonable" charges, ${ }^{134}$ Cline's "unreasonable" profits, ${ }^{135}$ Winters' "so massed as to become vehicles for inciting," 136 Herndon's "reasonable" time, ${ }^{137}$ Burstyn's "sacrilegious," and International Harvester's "real" price. ${ }^{138}$ These are phrases of inherent discontrol. Not all such statutes have been voided, of course. ${ }^{139}$ Many legal responsibilities may be made to turn-as many common-law duties have traditionally turned-upon the "reasonableness" of conduct as viewed by some trier of fact. But it is in this realm, where the equilibrium between the individual's claims of freedom and society's demands upon him is left to be struck ad hoc on the basis of a subjective evaluation-as also in the realm of more obviously absolute official discretion ${ }^{140}$ - that there exists the risk of continuing irregularity with which the vagueness cases have been concerned.

134 Ch. 53, 40 Stat. 277 (1919), as amended, ch. 80, 41 Stat. 297 (1919).

135 Colo. Acts 1913, ch. 161.

136 This language is that of the state court's gloss on the statute, N.Y. Sess. Laws 1941, ch. 925, \& 1, People v. Winters, 294 N.Y. 545, 550, 63 N.E.2d 98, 100 (1945), rev'd sub nom. 333 U.S. 507 (1948).

137 This language is that of the state court's gloss on the statute. Ga. Acts 1866, art. 214, $\S 1,2$, Herndon v. State, 179 Ga. 597, 600, 176 S.E. 620, 622 (1934), appeal dismissed sub mom. Herndon v. Georgia, 295 U.S. 441 (1935).

$138 \mathrm{Ky}$. Const. \$198, International Harvester Co. of America v. Kentucky, 234 U.S. 216 (1914). See also the judicial disapproval expressed in United States v. Shreveport Grain \& Elevator Co., 287 U.S. 77 (1932) ("reasonable" variations) (statute construed to avoid constitutional question); United States v. Pennsylvania R.R., 242 U.S. 208 (1916) ("reasonable" request; "normal" shipments) (question reserved); Chicago \& N.W. Ry. v. Dey, 35 Fed. 866 (Brewer, Circuit Judge, 1888) ("reasonable" rates) (question reserved). While undoubtedly in none of these last cited cases would a vagueness argument be successful today, they are exemplary of the reactions of federal judges to such broad grants of delegation when the potver exercisable under the grants is capable of touching interests regarded (in the era of the judging) as to be particularly safeguarded.

139 Boyce Motor Lines, Inc. v. United States, 342 U.S. 337 (1952) ("so far as practicable") ; United States v. Petrillo, 332 U.S. 1 (1947) ("in excess of the number of employees needed"); United States v. Ragen, 314 U.S. 513 (1942) ("reasonable allowance") ; Old Dearborn Distrib. Co. v. Seagram-Distillers Corp., 299 U.S. 183 (1936) ("fair and open competition"); Sproles v. Binford, 286 U.S. 374 (1932) ("shortest practicable route"); Baltimore \& O.R.R. v. Groeger, 266 U.S. 521 (1925) ("proper condition and safe to operate ... without unnecessary peril"); Mahler v. Eby, 264 U.S. 32 (1924) ("undesirable residents"); Edgar A. Levy Leasing Co. v. Siegel, 258 U.S. 242 (1922) ("unjust and unreasonable" or "oppressive" rent); Nash v. United States, 229 U.S. 373 (1913) (rule of reason).

140 These are cases involving standards for administrative licensing to speak or exhibit publicly. In each case the Court found a constitutional violation. Staub v. City of Baxley, 355 U.S. 313 (1958) ("character"; "effects upon the general welfare of its citizens"); Superior Films, Inc. v. Department of Educ., 346 U.S. 587 (1954) (per curiam) ("in the judgment and discretion of the board . . of a moral, educational or amusing and harmless character"; state court read "harmless" as conjunctive with each of the other requisites, 159 Ohio St. 315, 112 N.E.2d 314 (1953)); Gelling v. Texas, 343 U.S. 960 (1952) (per curiam) (board "is of the opinion" film would be "prejudicial to the best interests of the people"); Niemotko v. Maryland, 340 U.S. 268 (1951) (authority exercised without statutory basis; no standards). Cf. Cantwell v. Connecticut, 310 U.S. 296 (1940) (count five) (common-law crime of inciting breach of peace). Compare Fahey v. Mallonee, 332 U.S. 245 (1947) (authority given banking commission to order banks into receivership; no standard prescribed for exercise of discretion; delegation sustained). 
To say this much is to establish the conditions for the incidence of a case of unconstitutional uncertainty, not to determine its outcome. Given these elements-a delegation of power to make particular judgments of value in the application of social coercion to private activity which may lie within the shelter of some specific constitutional guarantee-the ultimate response of the Court will depend upon the nature of the individual freedom menaced, the probability of its violation, the potential deterrent effect of the risks of irregularity and violation upon its exercise, and the practical power of the Court itself to supervise the scheme's administration. It is evident that the first amendment freedoms receive most solicitous protection from today's Court. ${ }^{141}$ The probability of their deprivation has been consistently regarded as a function of what kind of tribunal is empowered to make the potentially deprivative value judgment. Power given to courts appears more tolerable than power given to administrative agencies, ${ }^{142}$ and, where licensing functions are entrusted to agencies, the demonstrated willingness of state courts to curb administrative discretion (as opposed to the mere assertion that the state courts would curb administrative discretion ${ }^{143}$ ) has been determinative. Similarly, the extent to which trial judges ride herd on their juries is important, ${ }^{144}$ as is the question whether state or federal organs will be in charge of the regulation at the fact-finding level..$^{145}$ And the severity of the sanction has an obvious influence upon the degree to which the freedom may be stifled by the mere existence of the statute. ${ }^{146}$ Regarding the Supreme Court's own power of control, the state-federal distinction is again significant, ${ }^{147}$ as is the articulateness of state judges in the exposition of the guiding standards of state law, ${ }^{148}$ and the existence or nonexistence, in those standards, of formula-

141 See notes 38-40 supra and accompanying text.

142 See note 78 supra. Compare Kingsley Books, Inc. v. Brown, 354 U.S. 436 (1957), with Commercial Pictures Corp. v. Regents of Univ. of N.Y., reported in Superior Films, Inc. v. Department of Educ., 346 U.S. 587 (1954) (per curiam), reversing 305 N.Y. 336, 113 N.E.2d 502 (1953).

143 Compare Poulos v. New Hampshire, 345 U.S. 395 (1953), with Cantwell v. Connecticut, 310 U.S. 296 (1940), and Hague v. CIO, 307 U.S. 496 (1939).

144 Compare Herndon v. Lowry, 301 U.S. 242 (1937), and Stromberg v. California, 283 U.S. 359 (1931), with Dennis v. United States, 341 U.S. 494 (1951), and Feiner v. New York, 340 U.S. 315 (1951). In People v. Winters, 294 N.Y. 545, 551, 63 N.E.2d 98, 100-01 (1945), rev'd sub nom. Winters v. New York, 333 U.S. 507 (1948), the court of appeals wrote: "In the nature of things there can be no more precise test of written indecency or obscenity than the continuing and changeable experience of the community as to what types of books are likely to bring about the corruption of public morals or other analogous injury to the public order. Consequently, a question as to whether a particular publication is indecent or obscene in that sense is a question of the times which must be determined as a matter of fact. ..." Where the framing of legal issues is sufficiently precise, the Court itself can exercise some measure of control by re-examination of inferences drawn by the jury. Fiske v. Kansas, 274 U.S. 380 (1927).

145 See note 80 supra.

146 See note 16 supra.

147 See notes 92-97 supra and accompanying text.

148 Compare State v. Derrickson, 97 N.H. 91, 81 A.2d 312 (1951), subsequent proceedings aff'd sub nom. Poulos v. New Hampshire, 345 U.S. 395 (1953), and 
tions sufficiently familiar to traditional judicial experience to give the Court a lever for review. ${ }^{149}$ Finally, into the process of weighing these considerations there enters that principle which is always a force in the Court's deliberations, precisely because the Court is charged with the preservation, in balance, of a complex lot of social and individual values: the principle of necessity. ${ }^{150}$ The maintenance of order is the precondition of any freedom in a society, and where the subject matter of regulation is such as to make unfeasible modes of law administration other than those which involve ad hoc judgments, considerable pressures are created in favor of permitting an ad hoc judgment scheme. ${ }^{151}$ Whether those pressures will succeed depends not merely upon narrow questions as to the naked comprehensibility of a statutory phrase, but upon the entire context

State v. Cox, 91 N.H. 137, 16 A.2d 508 (1940), aff'd sub nom. Cox v. New Hampshire, 312 U.S. 569 (1941), with State v. Gelling, 157 Tex. Crim. 516, 247 S.W.2d 95, rev'd sub nom. Gelling v. Texas, 343 U.S. 960 (1952) (per curiam), and Superior Film, Inc. v. Department of Educ., 159 Ohio St. 315, 112 N.E.2d 311 (1953), rev'd, 346 U.S. 587 (1954). See also Roth v. United States, 354 U.S. 476 (1957).

149 See notes 82 and 83 supra and accompanying text.

150 The theme that "the Constitution does not require impossible standards," United States v. Petrillo, 332 U.S. 1, 7-8 (1947), is a frequently recurring one in the Court's opinions. See Roth v. United States, 354 U.S. 476 (1957) ; Boyce Motor Lines, Inc. v. United States, 342 U.S. 337 (1952); Sproles v. Binford, 286 U.S. 374 (1932); Mahler v. Eby, 264 U.S. 32 (1924) ; Miller v. Strahl, 239 U.S. 426 (1915). Of equal indicativeness to what the Court has said concerning necessity is what the Court has in fact done. It has consistently sustained statutory formulas of approximation or relationship where more precise articulation would have been incapable of practical administration. E.g., United States v. Kahriger, 345 U.S. 22 (1953) ("engaged in the business of . ..") ; Gorin v. United States, 312 U.S. 19 (1941) ("connected with the national defense") ; United States v. Alford, 274 U.S. 264 (1927) (crime to build fire "near" timber); Waters-Pierce Oil Co. v. Texas, 212 U.S. 86 (1909) ("tends to"; "reasonably calculated to"). It has sustained the use of "kosher" in a statute whose purpose was fixing standards for the permissibility of the use of the term "kosher" by persons purporting to sell "kosher" meat. N.Y. Sess. Laws 1922, ch. 58, at 1315, Hygrade Provision Co. v. Sherman, 266 U.S. 497 (1925). It has permitted the incidence of regulation to turn upon a calculation of the physical properties of particular oil wells in particular cases where disparate conditions made uniform standards unworkable. CAL. PUB. Resources CODE $\$ 3300$, Bandini Petroleum Co. v. Superior Court, 284 U.S. 8 (1931). On the other hand, it has treated vigorously statutes whose indefiniteness was evidently the result of sloppy drafting. E.g., United States v. Cardiff, 344 U.S. 174 (1952); United States v. Evans, 333 U.S. 483 (1948); United States v. Reese, 92 U.S. 214 (1875). The "necessity" of a particular mode of regulation will depend upon comparison with alternative modes-not limited to other possible verbal forms but including also other possible enforcement methods. See Champlin Ref. Co. v. Corporation Comm'n, 286 U.S. 210 (1932) (administrative regulation allowed where self-enforcing penal provisions are too indefinite).

151 "This argument in substance denies to the legislature the power to use a generic description, and if pressed to its logical conclusion would practically nullify the legislative authority by making it essential that legislation should define, without the use of generic terms, all the specific instances to be brought within it." Baltimore \& O.R.R. v. ICC, 221 U.S. 612, 620 (1911) (sustaining statutory exceptions for emergency, act of God, etc.). See also United States v. Ragen, 314 U.S. 513 (1942); Miller v. Oregon, 273 U.S. 657 (1927) (per curiam). Compare the Court's discussion of "reasonableness" as a common-law negligence standard in Cline v. Frink Dairy Co., 274 U.S. 445, 463-65 (1927) ; the Court's balancing of idiosyncratic factors in its own ad hoc evaluation in Feiner v. New York, 340 U.S. 315 (1951); the similar balancing in the opinions, in Kingsley Int'1 Pictures Corp. v. Regents of Univ. of N.Y., 360 U.S. 684 (1959), of Mr. Justice Frankfurter, id. at 697, and Mr. Justice Harlan, id. at 708. 
of the regulation attempted-the danger to the public interest of the activity as unregulated and the loss to the individual which results from its regulation. ${ }^{152}$

\section{Vagueness Analysis and the Functioning of the Court}

The considerations discussed above will determine the Court's reaction to a statute. But, assuming that this reaction is of impermissibility, they will not determine whether, in a particular litigation, a statute will be declared unconstitutional, or what opinion will be written. Alternative syntaxes are available. A municipal ordinance, for instance, might be void for vagueness or it might constitute an unallowable restriction on freedom of speech. It might be void "on its face" or void as applied. Different conceptions will bring about (or serve to rationalize) the writing of different opinions or even different judgments. Why a potential vagueness decision becomes an actual vagueness decision is a question involving still other factors.

Three seem particularly significant: problems of standing, of scope of review, and of the breadth of the Court's effective invalidation. Each of these factors may enter the judicial equation as cause or as effect in a particular case. Couching an issue of standing in terms of a statute "void on its face" may be a necessary means of effectuating desired Supreme Court control-consistent with doctrinal precedent-over this given individual's case; or it may constitute the affirmation of a doctrine designed to broaden that control over the whole of a class of cases which by their nature require peculiar methods of supervision. Vagueness may be employed as a device to expand the scope of federal review for this one case only; or the same holding may be regarded as laying the foundation for protection of the Court's reviewing function in all of those future cases in which the indeterminacy of state rules of law would otherwise frustrate it. Probably here, as elsewhere in the judicial process, there is fused the manipulation of principles to achieve results and the determination of results under the felt compulsion of principles.

\section{Standing}

The long established saw that one may not invoke the constitutional rights of another ${ }^{153}$ has traditionally been held to imply, in the case of a statute whose application to $A$ would be within the legislative competence but whose application to $B$ would not, that if $A$ is convicted for violating

152 Compare Breard v. Alexandria, 341 U.S. 622 (1951) (ordinance outlawing door-to-door soliciting sustained), with the Los Angeles, Milwankee, and Worcester cases in Schneider v. State, 308 U.S. 147 (1939) (ordinances outlawing distribution of handbills on public streets voided). Compare Electric Bond \& Share Co. v. SEC, 303 U.S. 419 (1938) (registration provision for public utility holding companies sustained), with Thomas v. Collins, 323 U.S. 516 (1945) (registration provision for union organizers voided as applied to public speaker soliciting membership).

153 E.g., United States v. Raines, 362 U.S. 17 (1960); Tileston v. Ullman, 318 U.S. 44 (1943); Frothingham y. Mellon, 262 U.S. 447 (1923). 
the statute, he may not challenge his conviction on the grounds that $B$, who is also included within the statutory terms, would be immune from conviction. ${ }^{154}$ Simply to state the precept in these terms points up immediately the potentialities of a "vagueness" analysis for standing problems. The realm of the overly broad statute-the statute with both constitutional and unconstitutional applications with both $A$ and $B$ inclusions-has, from Herndon v. Lowry through Winters and Burstyn to Staub v. Baxley, ${ }^{155}$ been subject to claims of unconstitutional uncertainty. ${ }^{156}$ But if this is so, the complexion of $A$ 's case changes. He may now object to the statute which is unconstitutional as to $B$. Of course (as the saw goes) he may not rely on $B$ 's constitutional rights. Nor does he. He is now relying on his own constitutional right not to be subjected to a vague statute--one which is vague because it includes both $B$ and himself. $H e$ is, in the jargon, attacking the statute "on its face." 157

The comparison of factually similar cases illustrates the utilization of vagueness analysis for standing purposes. In Smiley $v$. Kansas, ${ }^{158}$ the defendant, Smiley, was shown to have been instigatory in arranging a purchase-allocation agreement among a number of competing grain eleyator operators and was convicted of violating section 1 of the Kansas antitrust act, ${ }^{159}$ which in broad terms banned virtually all restraints of trade. Smiley, pointing out that the act "went too far," argued interference with freedom to contract through the state court system to the United States Supreme Court and lost at all levels. The Supreme Court adopted the purest. are-you-in-or-are-you-out analysis:

It may be conceded for the purposes of this case that the language of the first section is broad enough to include acts beyond the police power of the State and the punishment of which would unduly infringe upon the freedom of contract. At any rate we shall not attempt to enter into any considerations of that question. The Supreme Court of the State held that the acts charged and proved against the defendant were clearly within the terms of the statute, as well as within the police power of the state; and that the statute could be sustained as a prohibition of those acts irrespective of the question whether its language was broad enough to include acts and conduct which the legislature could not rightfully restrain. ${ }^{\mathbf{1 8 0}}$

154 E.g., Yazoo \& Miss. V.R.R. v. Jackson Vinegar Co., 226 U.S. 217 (1912) Hatch v. Reardon, 204 U.S. 152 (1907) ; Jaehne v. New York, 128 U.S. 189 (1888). See generally Stern, Separability and Separability Clauses in the Supreme Court, 51 HARv. L. REv. 76, 89-94, 101 (1937).

155355 U.S. 313 (1958).

156 See text following note 48 supra, and cases cited in note 73 supra. See also Thornhill v. Alabama, 310 U.S. 88 (1940); Stromberg v. California, 283 U.S. 359 (1931).

167 See note 224 infra.

158196 U.S. 447 (1905).

159 Kan. Gen. Stat. Ann. § 50-101 (1949).

160196 U.S. at 454-55. 
The first sentence of this passage might well have been taken from Smith v. Cahoon. ${ }^{161}$ But what follows is from a different legal universe. ${ }^{162}$ That the cases are on all fours is confirmed by the state court opinion in Smiley, which (in language essentially identical to that of the Florida Supreme Court in Smith v. Cahoon ${ }^{163}$ ) concludes:

[A]ssuming the general phraseology of the statute to be comprehensive of classes of persons who cannot be rightfully included therein, . . . the general doctrine is that only the invalid parts of a statute are without legal efficacy ... [T] he rule . . . applies . . . to exclude from the operation of the statute subjects and classes of things lying without the legislative intent, although comprehended within the general terms of the act ....

. . We construe the general words of our statute to be comprehensive only of those cases which are the rightful subjects of legislation of the kind in question. ${ }^{164}$

In short, the Kansas opinion furnishes no more enlightenment as to the scope of its statute than does Florida's. The only distinction between the two cases is that in 1931 the Supreme Court found for Smith a "vagueness" handle which it could not find in 1905 for Smiley. ${ }^{165}$

Similarly, in Fox v. Washington, ${ }^{186}$ the defendant, Fox, published an article denouncing certain "prudes" who had complained to police and inspired the suppression of a nudist colony in which, apparently, Fox was interested. He was convicted for violation of a statute prohibiting the circulation of any written matter "having a tendency to encourage or incite the commission of any crime, breach of the peace, or act of violence, or which shall tend to encourage or advocate disrespect for law. . . ." 167 Mr. Justice Holmes for the Court, sustaining the statute as against first amendment and void-for-vagueness contentions, said:

So far as statutes may fairly be construed in such a way as to avoid doubtful constitutional questions they should be so construed; . . . and it is to be presumed that state laws will be construed in that way by the state courts. We understand the state court by implication at

161 See text accompanying notes 59-62 supra.

162 See discussion in text accompanying note 62 supra.

163 See text accompanying note 61 supra.

164 State v. Smiley, 65 Kan. 240, 247-56, 69 Pac. 199, 202-04 (1902).

165 It is true that Smith $v$. Cahoon involved uncertainty (if any) as to which sections were applicable to what persons, whereas Smiley involved uncertainty (if any) as to the persons to whom a single section was applicable. But from the point of view of degree of certainty, this seems a distinction without a difference. $C f$. Stern's discussion of separability in the two distinguished but assimilated cases of (1) valid and invalid applications of a single provision, and (2) valid and invalid provisions in a single act (or section). Stern, supra note 154, at 82.

160236 U.S. 273 (1915).

107 Wash. Laws 1909, ch. 249, §312. 
least to have read the statute as confined to an actual breach of law. - . It does not appear and is not likely that the statute will be construed to prevent publications merely because they tend to produce unfavorable opinions of a particular statute or of law in general. In this present case the disrespect for law that was encouraged was disregard of it-an overt breach and technically criminal act. . . . That is all that has happened as yet, and we see no reason to believe that the statute will be stretched beyond that point.

If the statute should be construed as going no farther than it is necessary to go in order to bring the defendant within it, there is no trouble with it for want of definiteness. . . . 188

This was 1915. Yet in 1948 when Murray Winters had been found guilty of selling books that were "nothing but stories and pictures of criminal deeds of bloodshed and lust," ${ }^{169}$ and convicted under a statute ${ }^{170}$ which, as construed by the New York Court of Appeals, prohibited the circulation of "collections of pictures or stories of criminal deeds of bloodshed or lust . . . so massed as to become vehicles for inciting violent and depraved crimes against the person," 171 the Supreme Court of the United States reversed.172 It said nothing about "construing the statute no farther than it is necessary to go in order to bring the defendant within it." It did not ask whether Winters was so far within the sphere of immunity of the first amendment ${ }^{173}$ that, were the statute so construed, it could not validly be applied to him. It found the statute overbroad and vague, ${ }^{174}$ and squarely within the rule that "a statute so vague and indefinite, in form and as interpreted, as to permit within the scope of its language the punishment of incidents fairly within the protection of the guarantee of free speech is void, on its face, as contrary to the Fourteenth Amendment." 175

108236 U.S. at 277.

169 People v. Winters, 294 N.Y. 545, 551, 63 N.E.2d 98, 100 (1945).

170 N.Y. Sess. Laws 1941, ch. 925, §1.

171294 N.Y. at 550, 63 N.E.2d at 100.

172 Winters v. New York, 333 U.S. 507 (1948).

173 Where "first amendment" is used here in the context of state-action cases, it is intended to refer, of course, to so much of first-amendment-like protection as the fourteenth gives. See De Jonge v. Oregon, 299 U.S. 353, 364 (1937) ; Palko v. Connecticut, 302 U.S. 319, 324-25 (1937) (dictum).

174 Commentators who are inclined to view the doctrines of vagueness and overbroadness as distinct have had trouble with Winters. Collings, Unconstitutional Uncertainty-An Appraisal, 40 CoRNeLL L.Q. 195, 217-70 (1955), puts the case in the overboard group; Bernard, Avoidance of Constitutional Issues in the United States Supreme Court: Liberties of the First Amendment, 30 MICH. L. REv. 261 (1951), tags it "vagueness." Clearly, if there were two wholly isolable classes, Winters would have to be placed in both. See 333 U.S. at 509-10, 518-20.

175333 U.S. at 509-10. Winters and $F o x$ would not seem distinguishable in terms of their respective treatments by the state courts. As Mr. Justice Holmes' language-"presumed," "we understand," "by implication" (see text at note 168 supra)-suggests, the holding of the Washington court in State v. Fox, 71 Wash. 185,127 Pac. 1111 (1912), gives him little support for a narrow reading. That opinion does say that Fox's article "is not a criticism of the law, but was calculated to, and 
The Winters-Smith approach gives the Court an extensive degree of doctrinal freedom. This is so in part because the prerequisite to its employment-the existence of an indefinite or overly broad statute-is the very question, on the merits, which is before the Court. ${ }^{176}$ Especially since the "indefinite" tag is one which (as Smith and Smiley demonstrate) may often be equally reasonably applied or not applied to the same circumstances, the Justices are relatively free to look to the particular facts of a state court defendant's case, as exigencies move them. ${ }^{177}$ Moreover, even when the tag has been applied and an "indefiniteness" syntax governs, the course of decision is not foreclosed. There exists a fire door at the other end of the doctrine. Winters-Smith does not do away with the requirement of standing. What it does do is shift the standing question from "are you within the scope of constitutional immunity?" to "are you within the scope

did, incite the violation of the law," 71 Wash. at 187, 127 Pac. at 1112, but this is a description of the case at bar, not a delimitation of the statute. The New York Winters opinion contains similar language: "In short, we have here before us accumulations of details of heinous wrongdoing which plainly carried an appeal to that portion of the public who (as many recent records remind us) are disposed to take vice for its own sake." People v. Winters, 249 N.Y. 545, 551, 63 N.E.2d 98, 100 (1945). A further example of the Smiley-Smith, Fox-Winters type is provided by consideration of the courses of litigation culminating in Whitney v. California, 274 U.S. 357 (1927), and Stromberg v. California, 283 U.S. 359 (1931).

176 Inasmuch as the defendant may constitutionally be convicted only of the crime with which he is charged, Stirone v. United States, 361 U.S. $212(1960)$, and Cole v. Arkansas, 333 U.S. 196 (1948), the question will not be as to the absolute unamenability of his conduct to state regulation however designed, but as to whether enforcement of the terms of the statute as drafted will attach impermissible liabilities to the incidents of his conduct which it seeks to regulate. This means, in a free speech case, that there are two dimensions in which the Court may find indefiniteness: whether defendant is inside or outside the sweep of the statute, e.g., Winters v. New York, 333 U.S. 507, 518-19 (1948), or whether (under the statute) he is within or without the protective reach of the first amendment, e.g., Herndon v. Lowry, 301 U.S. 242, 261-64 (1937). A defendant as to whom a statute is "vague" in either dimension will have standing to press its unconstitutionality. See United States v. CIO, 335 U.S. 106, 151 (1948) (Rutledge, J., concurring).

177 Query: why was the statute in Thornhill v. Alabama, 310 U.S. 88 (1940), broader than that in Valentine v. Chrestensen, 316 U.S. 52 (1942)? Why was the statute in Herndon v. Lowry, 301 U.S. 242 (1937), broader than that in Dennis v. United States, 341 U.S. 494 (1951)? Why did the Court talk "vagueness" as regards the second count in Cantwell v. Connecticut, 310 U.S. 296 (1940), but no "vagueness" in Feiner v. New York, 340 U.S. 315 (1951)? Note that vagueness analysis has traditionally been invoked by the Court in another class of cases posing some of the same-but also some rather different-standing considerations as those posed by the attacks on state statutes in the Winters-Stromberg-Thornhill group of cases. In cases like James v. Bowman, 190 U.S. 127 (1903), and United States v. Reese, 92 U.S. 214 (1875), criminal defendants who were clearly and indisputably within both the purview of a federal statute and the constitutional power of Congress to regulate by such a statute (if applied only to situations like theirs) were permitted to challenge the statute and have it declared unconstitutional. Seemingly in accord are the TradeMark Cases, 100 U.S. 82 (1879). None of these decisions seems to recognize a standing problem as such; all treat the issue as whether or not a statute is to be narrowly construed so as to save its constitutionality when it is evident that Congress in fact wanted to step over the forbidden line. Inasmuch as problems of severability in the interpretation of federal laws may reflect upon the Court's conception of a litigant's posture in these cases, it is difficult to ascertain to what extent "vagueness' is here used to expand standing. Compare Reese, and Bowman, with United States v. Raines, 362 U.S. 17 (1960). The state law cases, where severability is not ordinarily an issue of federal competence, present more clearly the vagueness-standing interrelationship. 
of statutory indefiniteness?" 178 To challenge a statute as vague or overreaching, a litigant must still be one as to whom it is vague or whom it may overreach. ${ }^{170}$ This residual standing requirement turned the case in Williams $v$. United States, 180 where, because it was "as plain as a pikestaff" that to beat a confession out of a prisoner was to deprive him of due process, ${ }^{181}$ Williams was unsuccessful in challenging as too vague the provision of the Civil Rights Act making criminal the subjection, under color of law, of any person "to the deprivation of any [constituitonal] rights. . ."182 The requirement was invoked again, in somewhat different terms, in Dennis $v$. United States, ${ }^{183}$ where the petitioners' vagueness contentions were found "particularly nonpersuasive when presented by petitioners, who, the jury found, intended to overthrow the Government as speedily as circumstances would permit. . . . A claim of guilelessness ill becomes those with evil intent." 184 But where it is felt that the Court's

178 Bernard, supra note 174, the only commentator found who has discussed the implications of the "indefiniteness" concept for problems of standing, seems not to have recognized this principle of a standing requirement once removed. Considering the first amendment "indefiniteness" cases out of context of the more general perspective of vagueness doctrines, he reads Thornhill v. Alabama, 310 U.S. 88 (1940), see text accompanying note 186 infra, as a declaration by the Court that any defendant can assail an overbroad statute, a proposition which he approves upon reasoning grounded in the "preferred" position of first amendment freedoms. Bernard wrote a year too early to have to explain why this "preference" has not operated to do away with the standing requirement in other of its aspects in first amendment cases, Doremus v. Board of Educ., 342 U.S. 429 (1952), no more than it has obviated the necessity of a constitutional claimant's observing the other fixed requirements of Supreme Court jurisdiction, Edelman v. California, 344 U.S. 357 (1953). He wrote in time, however, to take note of Dennis v. United States, 341 U.S. 494 (1951), see text accompanying notes 183-84 infra, and to be disturbed by what he regarded as its unjustifiable incursion into the Thornhill principle.

179 United States v. Wurzbach, 280 U.S. 396 (1930). See also Jordan v. De George, 341 U.S. 223 (1951), in which the unarticulated point of difference between the majority and dissenting opinions is precisely this standing problem. The issue was the unconstitutional uncertainty of "crime involving moral turpitude" as a standard for deportation, Immigration Act $\S 119$ (a), 39 Stat. 889, as amended, 8 U.S.C. $\$ 155$ (a) (1958). Defendant had been convicted of conspiracy to defraud the United States of certain taxes. The majority analysis starts from the premise that the determinative question in this case is whether "crime involving moral turpitude" is unclear in its reference to such a conviction, and the Court, finding that "without exception, federal and state courts have held that a crime in which fraud is an ingredient involves moral turpitude," 341 U.S. at 227, holds the statute not too vague. The dissenters ask: just what does moral turpitude mean? And, looking to its employment throughout the many areas of the law (not "fraud" cases alone), they find the term fatally indefinite.

180341 U.S. 97 (1951).

$181 \mathrm{Id}$. at 101. Very articulately in accord is Mr. Justice Murphy's opinion in Screws v. United States, 325 U.S. 91, 136-37 (1945), and it is not difficult to read the "scienter" requirement injected by Mr. Justice Douglas' opinion in the same case as intended to provide a hitching post to which a no standing argument could attach. See id. at 104-05.

18218 U.S.C. $\$ 242$ (1958).

183341 U.S. 494 (1951).

184 Id. at 515. Note that Williams and Dennis are federal cases in which the Court may have felt that it could exercise sufficient control under its ordinary processes of review, without invoking a vagueness syntax. Consider the Court's statement that "where there is doubt as to the intent of the defendants, the nature of their activities, or their power to bring about the evil, this Court will review the convictions with the 
effective reviewing power requires its exercise, Winters-Smith remains available. Herndon $v$. Lowery seems to have invoked it. ${ }^{185}$ And in Thornhill v. Alabama, where defendant had been convicted under a statute punishing persons "who, without a just cause or legal excuse therefor, go near to or loiter about the premises or place of business of any other person . . . engaged in a lawful business, for the purpose, or with the intent of influencing or inducing other persons not to ... have business dealings with, or be employed by such [person]," ${ }^{186}$ Mr. Justice Murphy gave the doctrine its most articulate expression:

There is no occasion to go behind the face of the statute or of the complaint for the purpose of determining whether the evidence, together with the permissible inferences to be drawn from it, could ever support a conviction founded upon different and more precise charges. . . . The State urges that petitioner may not complain of the deprivation of any rights but his own. It would not follow that on this record petitioner could not complain of the sweeping regulations here challenged.

There is a further reason for testing the section on its face. Proof of an abuse of power in the particular case has never been deemed a requisite for attack on the constitutionality of a statute purporting to license the dissemination of ideas. . . . One who might have had a license for the asking may . . . call into question the whole scheme of licensing when he is prosecuted for failure to procure it. . . An accused, after arrest and conviction under such a statute, does not have to sustain the burden of demonstrating that the State could not constitutionally have written a different and specific statute covering his activities as disclosed by the charge and the evidence introduced against him. ${ }^{187}$

In practice, in the first amendment area, the line between DennisWilliams and Thornhill has meant that the Court will treat differently litigants who attack state regulation delegating to executive agencies widely discretionary or imprecisely measured powers of censorship, and litigants who attack state criminal statutes of blanket and uniform prohibition but which overreach protected liberties in some of their potential applications. ${ }^{188}$

scrupulous care demanded by our Constitution." Id. at 516. It is significant that the trial court in Williams had pursued precisely the formula of jury charge prescribed by the Supreme Court in Screzes. See Williams, 341 U.S. at 99 . Furthermore, two lower federal courts had ridden a very tight rein on the jury in Demis. See Judge Hand's careful opinion in 183 F.2d 201 (1950). Very similar to Williams and Demmis is the Court's treatment of American Communications Ass'n v. Douds, 339 U.S. 382 (1950).

185301 U.S. 242 (1937). For more extensive discussion of this aspect of Herndon, see text accompanying notes $210-18$ infra.

186 Ala. Laws 1921, No. 23, §2.

187310 U.S. 88, 96-98 (1940).

188 Compare Kunz v. New York, 340 U.S. 290 (1951), with Feiner v. New York, 340 U.S. 315 (1951), and Chaplinski v. New Hampshire, 315 U.S. 568 (1942). Com- 
In the former class, the Court will close its eyes to the particular facts of the individual's situation and allow him to argue that the statute might encompass in its ambit forbidden repressions. ${ }^{189}$ In the latter, whether the Court will require a litigant to demonstrate that his own repression is in fact a forbidden one will depend upon the level of discrimination which is invoked to set off protected from nonprotected groups. ${ }^{190}$ Both classes

pare the Schneider case in Schneider v. State, 308 U.S. 147 (1939), with Breard v. Alexandria, 341 U.S. 622 (1951). Compare the rationale of the Court's opinion in Staub v. Baxley, 355 U.S. 313 (1958), with that of Thomas v. Collins, 323 U.S. 516 (1945).

189 Staub v. Baxley, supra note 188; Largent v. Texas, 318 U.S. 418 (1943); Cantwell v. Connecticut, 310 U.S. 296 (1940). This is clearly evident in Superior Films, Inc. v. Department of Educ., 346 U.S. 587 (1954) (per curiam). See the description of the film there banned in the opinion below, 159 Ohio St. 315, 112 N.E.2d 311 (1953), and compare with the several opinions of the Court in Kingsley Int'l Pictures Corp. v. Regents of Univ. of N.Y., 360 U.S. 684 (1959). Note that Commercial Pictures Corp. v. Regents of Univ. of N.Y., 346 U.S. 584 (1954), was decided per curiam with Superior Films on the authority of Joseph Burstyn, Inc. v. Wilson, 343 U.S. 495 (1952). Yet compare the nature of the two pictures involved, "The Miracle" and "La Ronde." See 343 U.S. at 507-08 (Frankfurter, J., concurring) ("The Miracle") ; Commercial Pictures Corp. v. Regents of Univ. of N.Y., 305 N.Y. 336, 113 N.E.2d 502 (1953) ("La Ronde"). Note that the latter was banned by the censor as "immoral," while the former was deemed "sacrilegious." And see Gelling v. Texas, 343 U.S. 960 (1952), also reversed summarily on authority of Burstyn.

It is now established law that, although a state may require an individual to comply with the provisions of a "valid" licensing statute as a prerequisite to challenging the constitutional validity of the manner in which it is being administered in his particular case, Poulos v. New Hampshire, 345 U.S. 395 (1953), a criminal defendant may successfully defeat conviction for violation of a licensing statute which leaves administrative discretion at large, even though the defendant has never applied for a license and thus cannot demonstrate that it would have been refused him. Staub v. Baxley, 355 U.S. 313 (1958) ; Largent v. Texas, 318 U.S. 418 (1943); Jones v. Opelika, 316 U.S. 584, 603 (1942) (dissenting opinion), vacated per curiam, 319 U.S. 103 (1943) (adopting previous dissent); Cantwell v. Connecticut, 310 U.S. 296 (1940) ; the Schneider case in Schneider v. State, 308 U.S. 147 (1939); Lovell v. Griffin, 303 U.S. 444 (1938). And note the Supreme Court's treatment of the district court decree in Hague v. CIO, 307 U.S. 496 (1939).

190 A distributor of commercial handbills was not permitted, Valentine v. Chrestensen, 316 U.S. 52 (1942), to challenge the kind of antilittering ordinances held invalid as applied to political and labor pamphleteers in Kim Young v. California and Snyder v. Milwaukee, both reported in Schneider v. State, 308 U.S. 147 (1939). Similarly, a salesman of national magazines could not complain, Breard v. Alexandria, 341 U.S, 622 (1951), of the Green River ordinance held void at the suit of a Jehovah's Witness in Martin v. City of Struthers, 319 U.S. 141 (1943). (This is meaningful only if Breard be regarded as not overruling Martin, of course.) And note that the religious pamphleteers held exempt from peddlers' taxes in Murdock v. Pennsylvania, 319 U.S. 105,111 (1943), had to bring themselves within the scope of the first amendment. Probably the element which distinguishes these cases from those like Winters, Hermdon, Stromberg, and Thornhill, where defendants convicted under self-enforcing criminal provisions were allowed to attack those provisions without reference to the particular facts of their situation, is that the kind of categorization necessary to sort out the specific incident which (1) serves as the handle by which state law attaches to an individual case, and (2) serves as the lever which puts that case in or out of first amendment protection, is a grosser, more palpable discrimination in the Valentinetype case than in the Winters-type. While the commercial-noncommercial line may not be of indubitable clarity in every situation, it is reasonable to assume that the Court has felt itself better able to review that kind of pigeon-holing process on a cold record than the type of line drawing required in Winters. But note that when a similar pigeon-holing task was placed in administrative hands in the first instance, the regulation was voided. Cantwell v. Connecticut, 310 U.S. 296 (1940) (executive licensor is to "determine whether such cause is a religious one or is a bona fide object of charity or philanthropy ...".). 
of statutes are on a par for "indefiniteness," of course, inasmuch as both attempt to make the question of ultimate enforceability a constitutional guess. Indeed, the blanket self-enforcing statute gives less "fair warning" than the administered, censoring variety, for under a censorship scheme the individual can know in advance whether the state intends to try to employ its repressive powers against him; and inasmuch as the channels of prior review are open to him, he need make his first amendment challenge at his peril only if he selects to disobey instead of seeking a judicial safe conduct. $^{191}$ The critical distinctions which cause the executive-censor statutes to be more readily assailable are the consideration of the probability of irregularity and the susceptibility of federal control inherent in the two classes. The wider and more undefined is the discretion of that state organ which makes the initial individual-versus-government calculus on the particular facts it finds, the more probable becomes the incidence of erratic regulation and the less effective becomes Supreme Court review on the record. The "indefiniteness" approach is compensatory; it relaxes the standing requirement to the extent of the Court's apprehension of the risk resident in state law indeterminacy. It gives the Court a power to ignore the facts which is precisely coextensive with the state's power to "find" them. Yet it allows state patterns of regulation insofar as they lend themselves to effective control by the Court's usual processes of review-insofar, in effect, as they seem to assure that irregularity, when it occurs, will be palpable.

\section{Scope of Revieze}

This concept that the vagueness syntax is used to aid the Court's reviewing function by permitting an individual to complain of unconstitutionality when he has been subjected to state compulsion under a scheme of law whose imprecision in the framing of legal issues is such as to give the triers of fact a power to invade imperceptibly (and thus unreviewably) a realm of constitutionally protected personal liberties, without the necessity of that individual's demonstrating an actual invasion in his own case, points up the interrelationship between the problems of standing and scope of review. Practically, of course, since both "standing" and "scope of review" are used to limit the kind of questions which a given litigant may raise, they can serve as alternative modes of approach to the same result. This may be illustrated by positing defendant's conviction for a crime involving speech where, upon the undisputed facts of record, ${ }^{192}$ the Court cannot call unreasonable the trier's determination that defendant's conduct is without the bounds of first amendment protection ${ }^{193}$ (protection, that is, which the

191 See note 55 supra.

192 For expression of this basis as governing the scope of the Court's review, see authorities cited note 72 supra; Feiner v. New York, 340 U.S. 315, 316 (1951); Pennekamp v. Florida, 328 U.S. 331, 345 (1946), and cases there cited. (1941).

${ }^{193}$ See Milk Wagon Drivers v. Meadowmoor Dairies Inc., 312 U.S. 287, 294 
first amendment would afford against a "narrowly drawn" 194 statute). When it has tagged the statute "not narrowly drawn" the Court can upset the conviction either by allowing defendant to invoke hypothetical unconstitutionalities not actualized in his case-the standing doctrine articulated in Thornhill-or by reviewing the undisputed facts and finding unreasonable any determination that defendant's conduct is clearly without the bounds of protection. Thus, in effect, by shifting the focus of inquiry, a vagueness analysis expands the scope of the Court's review of fact just as, in Thornhill, the same shift of focus expanded the range of sufficient litigant's standing. ${ }^{195}$

Juxtaposition of the opinions in a number of cases presenting comparable litigated facts points up this principle in operation. In Gitlow v. New York, ${ }^{196}$ defendant was convicted for violation of a statute which outlawed advocating, advising, or teaching the duty, necessity, or propriety of overthrowing or overturning organized government by force or violence. ${ }^{197}$ The state put in evidence the Left Wing Manifesto of the Revolutionary Socialist Party, a pamphlet in whose publication and circulation defendant had admittedly been instrumental and which urged "mass political strikes and .. . revolutionary mass action for the conquest of the power of the state, . . . the annihilation of the bourgeois parliamentary state and the introduction of the transition proletarian state . . for the coercion and

194 See United States v. CIO, 335 U.S. 106, 141 (1948) ; Murdock v. Pennsylvania, 319 U.S. 105, 116 (1943); Mr. Justice Jackson's dissent appended to Douglas v. City of Jeannette, 319 U.S. 157, 175 (1943).

195 Other analogous devices are available to achieve a more rigorous control over the trier of fact without appearing to broaden the scope of review. In Terminiello v. Chicago, 337 U.S. 1 (1949), defendant had been convicted under a breach of the peace ordinance, ChICAGo, ILL., MunrCIPAL CODE $\$ 193-1$ (1939), for an inflammatory bit of oratory under already inflamed circumstances. The parties had litigated the constitutional issue through the courts below, and briefed and argued the issue in the Supreme Court, in terms of the existence vel non of a state of facts which rendered defendant's utterance, at the time it was made, a suppressible danger. But the Court (over the vehement dissent of Justices Frankfurter, Jackson, Burton, and Vinson) ignored this aspect and, seizing upon a phrase in the jury charge which authorized conviction if the defendant's conduct was of a type which, inzter alia, "stirs the public to anger [and] invites dispute, ..." the majority reversed on the ground that such a charge included activities fairly within the first amendment's protection. Inasmuch as jury charges are often somewhat disjointed compounds of state-requested and defense-requested instructions, overlapping and in part mutually contradictory, the Terminiello device is, like the vagueness analysis, frequently one which the Court may use or not use as it chooses. Compare Stromberg v. California, 283 U.S. 359 (1931), where the Court, entirely ignoring certain inconsistent charges given by the trial court for the defense, reversed because certain charges requested by the state and given by the trial court were too broad, with Burns y. United States, 274 U.S. 328 (1927), where the Court, in affirming, treated certain portions of the charge, confessedly overbroad in themselves, as in effect neutralized by other portions of the charge containing contradictory implications. The Burns decision also rested in part on the principles (1) that the charge must be read in the light of the evidence introduced, and (2) that defendant had not made sufficient objection to the charge to preserve the constitutional question-two principles strenuously argued by the dissent and quite ignored by the majority in Terminiello.

190268 U.S. 652 (1925).

197 N.Y. PEN. LAws $\$ 160-61$. 
suppression of the bourgeoisie." 198 The trial court refused to charge that imminent danger was an element of the offense, and the Supreme Court affirmed the conviction, on the rationale that where a legislature had regarded a class of speech as sufficiently dangerous to outlaw it per se, and where that class of speech (as seen by the Court) was in fact so dangerous as to justify its outlawry as a class, particular instances falling within the class could be punished constitutionally without showing clear and present danger in each specific defendant's case. ${ }^{199}$ Two years later the Court, in Fiske v. Kansas, ${ }^{200}$ was faced with a similar statute which outlawed the advocacy or affirmative suggestion of crime, physical violence, sabotage, or other unlawful acts or methods as a means of effecting industrial or political ends. ${ }^{201}$ Here again the evidence adduced to support the conviction was literary; but here the written matter (the preamble to the Constitution of the International Workers of the Workers, for which defendant had admittedly solicited members) went no further than to declare that "the working class and the employing class have nothing in common," that between these classes "a struggle must go on until the workers of the World organize as a class" and "take possession of the earth," and that "by organizing industrially we are forming the structure of the new society within the shell of the old." This was enough for the state supreme court, which held that the language need not affirmatively suggest physical violence for political ends "necessarily and as a matter of law"; that it sufficed to sustain a jury verdict that it be-as it here was-"open to that interpretation and . . capable of use to convey that meaning." 202 The Supreme Court reversed on the facts. Looking independently at the uncontested documentary evidence, it could discover "no suggestion in the preamble that the industrial organization of workers as a class for the purpose of getting possession of the machinery of production .. . was to be accomplished by any other than lawful methods. . . ." 203 Thus "the language of the preamble is essentially different from that of the manifesto involved in Gitlow. . . ."204 And again in De Jonge v. Oregon, ${ }^{205}$ Gitlow gave the Court no trouble. Conviction here was under a statute which, as read by the state court, outlawed assisting in the conduct of a meeting held by any organization which advocated crime, physical violence, or other unlawful means of effecting political change. ${ }^{206}$ Literature put in evidence was as $60 \mathrm{n} .2$.

198268 U.S. at 659 n.2. The manifesto is set out at length in 268 U.S. at 656-

199 Accord, Whitney v. California, 274 U.S. 357 (1927).

200274 U.S. 380 (1927).

201 Kan. Gen. Stat. Ann. $\$ \S 21-301,-303$ (1949).

202 State v. Fiske, 117 Kan. 69, 73, 230 Pac. 88, 90 (1924).

203274 U.S. at 386.

204 Ibid.

205299 U.S. 353 (1937).

206 Ore. Laws 1921, ch. 34, §§1-3, as amended, Ore. Laws 1933, ch. 459. 
unambiguously revolutionary as had been the Left Wing Manifesto, ${ }^{207}$ but its only relevant connection with defendant was that it was the product of the Communist Party, under whose auspices had been conducted a meeting at which he spoke.208 His speech itself had been innocuous, and, reversing, the Supreme Court had no need to reopen questions of fact. It held that the demonstrated relation between defendant and the syndicalist doctrines upon which the state sought to rest criminal responsibility was too tenuous-that the question "is not as to the auspices under which the meeting is held but as to its purpose; not as to the relations of the speakers, but whether their utterances transcend the bounds of the freedom of speech which the Constitution protects." 209

All of these statutes were susceptible of applications which contravened the first amendment; indeed, in Fiske and De Jonge, the Court found that such applications had been made. Yet there was no talk of overbroadness or indefiniteness. The lines of undisputed fact plus reasonable inference which cut between the cases were sufficiently gross, as between Gitlow and Fiske, to make apparent that the verbal formulation which the Court had approved as a tolerable adjustment of state and individual interests in the former case could not be used to characterize the latter. As between Gitlow and De Jonge, with the Court looking only to those incidents which the state regarded as germane, those lines supported the attachment of a rule of laze. Herndon v. Lozery ${ }^{210}$ presented other problems. There it was argued that Herndon was a paid Communist Party organizer, that he had enlisted a number of local residents, and that he had conducted and spoken at several meetings. The state put in evidence literature which had been found on Herndon's person and in his room at the time of his arrest ${ }^{211}$ literature which, while not as overtly sanguinary as Gitlow's, ${ }^{212}$ did declare the program of the party Herndon was organizing as comporting "confiscation of the landed property of the white landowners," "overthrow [of] the yoke of American imperialism in the Black Belt," immediate "mass actions such as demonstrations, strikes, tax boycott movements," "NATIONAL REBELLION," "changing the political organism," "an uprooting and re-

207 E.g., "the conquest of power by the proletariat is the violent overthrow of bourgeois power, the destruction of the capitalist State apparatus (bourgeois armies, police, bureaucratic hierarchy, the judiciary, parliaments, etc.), and substituting in its place new organs or proletarian power ... State v. De Jonge, 152 Ore. 315, 320,51 P.2d 674, 676 (1935). Long excerpts urging "mass action" including "strikes and demonstrations" and finally "the general strike conjointly with armed insurrection" are set forth id. at 320-26, 51 P.2d at 676-79.

208 Defendant was himself a member of the Party and spoke as its "representative" at the meeting, but the Court read the opinion below as regarding this aspect as immaterial to defendant's criminal responsibility. 299 U.S. at 362-63.

209299 U.S. at 365.

210301 U.S. 242 (1937).

211 There was no evidence that Herndon had distributed this literature to prospective recruits, but he had told police officers that it had been sent him for that purpose. 301 U.S. at 248.

212 The literature is described in detail in Herndon v. State, $178 \mathrm{Ga} .832,860-67$, 174 S.E. $597,612-15$ (1934). 
planting . . . (a revolution and not a reformation)." The crime was inducing others to join in any combined forcible resistance to the lawful authority of the state; ${ }^{213}$ the state court-reading such pamphlet phrases as "SMash the National Guard, the C.M.T.C. and R.O.T.C." as sufficiently importing violence, and finding an inferrable relationship between Herndon's activities and the literature he carried-held that the conviction was supported by the evidence. ${ }^{214}$

Arguably the Herndon statute ${ }^{215}$ was less "definite" than Gitlow's, "resistance" perhaps being a wider term than "overthrow." But the statute was certainly of the Gitlow type, and the Court could not employ the method it had used in De Jonge. Nor could it find, as it had in Fiske, that reasonable inference was insufficient to take defendant's conduct out of the first amendment-the verdict appeared impervious in this dimension. The rub in the Herndon record, however, was that, whatever conclusion reasonable inference might have reached on the facts, it was probable that Herndon's conviction was not in actuality the product of reasonable inference. Significantly, the trial judge had charged the jury that to convict they must find an intent to incite immediate serious violence, and it was only on appeal that the guilty verdict had been saved by holding that the requisite violence was that which might be expected within "a reasonable time." 216 Moreover, Herndon was negro, the state was Georgia, and there were indications of race prejudice in the record. ${ }^{217}$ This total perspective was insufficiently seizable to justify reversal within the ordinary scope of Supreme Court review of fact. But the Georgia regulation had in operation displayed the latitude it allowed for discontrol, irrationality, and irregularity. Vagueness analysis stepped into the breach and the court reversed:

Every person who attacks existing conditions, who agitates for a change in the form of government, must take the risk that if a jury

213 See text accompanying note 64-66 supra.

214 "Were these not the tools to be used by the defendant in the execution of his mission? Did he remain in Atlanta for about a year without using them? He told the officers that he was sent to Atlanta as a paid organizer for the Communist Party, and that the literature was sent to him from the headquarters of the party in New York City. Did he take the means and instruments supplied to him and fail to use them?" Herndon v. State, 178 Ga. 832, 856, 174 S.E. 597, 610 (1934).

$215 \mathrm{Ga}$. Acts 1866 , art. $214, \S \S 1,2$.

216 Herndon v. State, $179 \mathrm{Ga} .597,600,176$ S.E. 620, 622 (1934). This is on motion for rehearing of the earlier affirmance. See text accompanying notes 67-68 supra.

217 Herndon claimed, but could not establish, systematic exclusion of Negroes from the jury. Herndon v. State, 178 Ga. 832, 836-37, 174 S.E. 597, 600-01 (1934). Note that the trial was conducted in Fulton County, where sixteen years later the Supreme Court was to find systematic discrimination as a matter of law. Avery v. Georgia, 345 U.S. 559 (1953). See Williams v. Georgia, 349 U.S. 375 (1955). Herndon requested, but was not granted, the right to question the jurors individually as to race prejudice on voir dire. Herndon v. State, supra at $839-43,174$ S.E. at 602-04. Herndon objected to a state's witness referring to him as a "darky." The Georgia court, citing Webster's New International Dictionary for the proposition that the term was not opprobrious, held the reference nonprejudicial. Id. at 853, 174 S.E. at 609 . 
should be of the opinion he ought to have foreseen that his utterances might contribute in any measure to some future forcible resistance to the existing government, he may be convicted . . . . The law, as thus construed, licenses the jury to create its own standard in each case. . . No reasonably ascertainable standard of guilt is prescribed. ${ }^{218}$

\section{Extent of the Court's Invalidating Decision}

Still another literary evidence case, Stromberg v. California, ${ }^{219}$ provides an opportunity to view void-for-vagueness analysis at work in a further capacity. Stromberg was convicted for displaying a red flag as a symbol of opposition to organized government. ${ }^{220}$ To demonstrate the symbolic referent of the flag salute ceremonies, ${ }^{221}$ the state introduced books, similar to the Gitlowe Manifesto, from the library of the camp where the flag had been saluted. ${ }^{222}$ Here perhaps the Court might, had it wished, have taken a $D e$ Jonge approach and held as a general principle that while advocating violent overthrow might constitutionally be punished, flying a flag "as a symbol of" violent overthrow was, as a matter of law, too supposititious and subjective a matter for suppression. But the Court apparently found it inexpedient to deny the state, absolutely, the right to reach such conduct. Again it employed a "vague and indefinite" 223 rule and reversed. This election not to invoke a $D e$ Jonge-type analysis illustrates a third dimension, immediately connected with those of standing and scope of review, for which the utilization of a vagueness, as opposed to some form of straight "first amendment," syntax has practical implications. These involve the posture in which a Supreme Court determination of unconstitutionality leaves a state regulatory scheme. What does such a determination mean with respect to the state's power to punish some other defendant, on other facts, under this same statute? What does it mean with respect to the state's power to punish subsequent defendants in the precise situation of this defendant under another, different statute? Answers to these two questions are likely to be rendered-or avoided - under a finding of "indefiniteness" or a declaration that a statute is "void on its face." 224

218301 U.S. at 261-64.

219283 U.S. 359 (1931).

220 CAL. PEN. CODE $\S 403$ (a). This statement is somewhat oversimplified, but it will do for the purpose. This is the crime upon which, under a charge to the jury, the United States Supreme Court had to pass.

221 People v. Mintz, 106 Cal. App. 725, 729, 290 Pac. 93, 95 (Dist. Ct. 1930).

222 Ibid.

223283 U.S. at 369.

224 The statement that a litigant is attacking a statute "on its face" is one of multiple meanings. As used in the vagueness cases, it does not mean that the statute as written, as opposed to state court construction of it, is being tested. See note 4 supra. In the first amendment vagueness area it may mean what Mr. Justice Murphy meant by it in Thornhill: that a defendant can defeat his conviction under the statute by showing that it would be unconstitutional in some possible applications as construed, even though, were it limited in applicability to the circumstances of this case, it would be constitutional. Or it may mean, in Mr. Justice Black's words in United States v. Petrillo, 332 U.S. 1, 6 (1947), that "the section .. . is void in toto, barring all further actions under it, in this, and every other case." Apparently Mr. Justice Murphy is talking standing; Mr. Justice Black, effect. 
The ground rules which frame these problems, in terms of archetype cases, are relatively clear. Certainly the Court can, and frequently does, render decisions of invalidity of state statutes as applied which do not impair the constitutional enforceability, in other situations, of the statutory provisions involved. ${ }^{225}$ Severability problems in the aftermath of Supreme Court invalidations are ordinarily left to the states, ${ }^{226}$ and there is nothing of a special nature in the first amendment case to alter this principle. The commercial advertiser scattering handbills in Valentine v. Chrestensen ${ }^{227}$ could have been punished under the antilitter provisions which political and labor pamphleteers escaped in Kim Young v. California and Snyder v. Milwerkee, ${ }^{228}$ and there is no indication that the Fiske decision ${ }^{229}$ made totally inoperative Kansas' criminal syndicalism laws. ${ }^{230}$

The practical effect of such first-amendment-talking decisions, then, is to insulate a particular activity ${ }^{231}$ while reserving the question of the constitutionality of the state regulatory scheme insofar as it may comprehend other, dissimilar applications. ${ }^{232}$ This insulation, of course, does not mean that the activity is untouchable by the state. Often, by fastening upon incidents of it other than those to which the voided law attached ${ }^{233}$ or upon those same incidents plus others, ${ }^{234}$ the state may bring it under control; or perhaps the state may visit sanctions upon it other than those whose imposition was declared unconstitutional. ${ }^{235}$ These possible points of

225 Hanson v. Denckla, 357 U.S. 235 (1958), did not make totally void the constructive service provisions of Florida, nor did Shelley v. Kraemer, 334 U.S. 1 (1948), eradicate the general jurisdiction statute of Missouri.

226 See the extensive discussion in Stern, Separability and Separability Clanses in the Supreme Court, 51 HARv. L. Rev. 76, 90-94 (1937).

227316 U.S. 52 (1942).

228 Both cases reported in Schneider v. State, 308 U.S. 147 (1939).

229274 U.S. 380 (1927). See text accompanying notes 200-04 supra.

230 Note that it is not the generality or capacity for generic abstractions of a case which necessarily determines its effect in this regard. Fiske was a ruling on the evidence in one man's situation, while Snyder is reducible to a fairly general "proposition of law." Similarly of the "proposition of law" type are Thomas v. Collins, 323 U.S. 516 (1945), and Jones v. Opelika, 319 U.S. 103 (1943) (per curiam).

231 See also Craig v. Harney, 331 U.S. 367 (1947); Pennekamp v. Florida, 328 U.S. 331 (1946).

232 Solely in cases like $D e$ Jonge, or West Virginia Bd. of Educ. v. Barnette, 319 U.S. 624 (1943), or Smith v. California, 361 U.S. 147 (1959), where the only end the statutes in question sought to accomplish was that which the Supreme Court said they could not constitutionally accomplish, was the necessary effect of the Court's decision to negative the law entirely. In these instances the state's definition of the offense coincided with the Court's definition of the sphere of protection. Nothing remained to regulate.

233 Compare Giboney v. Empire Storage \& Ice Co., 336 U.S. 490 (1949), with AFL v. Swing, 312 U.S. 321 (1941).

234 As by adding a scienter requirement to the elements of the crime established by the ordinance in Smith v. California, 361 U.S. 147 (1959), or Lambert v. California, 355 U.S. 225 (1957).

235 As by punishing post hoc or by imposing civil liability for the communications which in Near v. Minnesota, 283 U.S. 697 (1931), were impermissibly made grounds for restraint of all future publications. Compare Beauharnais v. Illinois, 343 U.S. 250 (1952). 
access preserve a certain flexibility in the wake of the Court's decision, ${ }^{236}$ a flexibility which will be proportionately wider as the decision itself is more narrowly rested on its facts. ${ }^{237}$ Nevertheless, characteristically in these cases an individual should be able to expect that if the state can subsequently show no more to justify his suppression than it showed in the earlier assertion of state power struck down by the Court, the state will be denied access to the constitutionally protected area. In this aspect the cases are different in kind from those like Fozoler $v$. Rhode Island, ${ }^{238}$ where, reversing a conviction under an ordinance which, as construed, forbade religious exercises in public parks to certain sects but not to others, the Court expressly laid its decision on equal protection grounds. For Fowler, although it voided the statute in that form, alluded only by implication to defendant's right to address his congregation in a public park. ${ }^{239}$ Different, too, from both these types is a decision like Yick Wo v. Hopkins, ${ }^{240}$ finding unconstitutional the enforcement of a wooden laundry ordinance in such a manner as to discrimniate against Chinese in favor of Caucasians.

Traditionally and by their logic, the vagueness cases are of the nature of Fozeler $v$. Rhode Island. ${ }^{241}$ They purport to pass upon the legitimacy or illegitimacy of means, ${ }^{242}$ invalidating a particular regulation with regard to those as to whom it is indefinite ${ }^{243}$ and because it is indefinite, ${ }^{244}$ and reserving judgment as to whether the end sought to be achieved is achievable through more definite regulation. ${ }^{245}$ Again this means that where

236 Some decisions suggest the means of their own circumvention. See Wiemann v. Updegraff, 344 U.S. 183, 189-91 (1952), distinguishing Adler v. Board of Educ., 342 U.S. 485 (1952).

237 Compare International Bhd. of Teamsters v. Hanke, 339 U.S. 470 (1950), with Bakery Drivers v. Woh1, 315 U.S. 769 (1942).

238345 U.S. 67 (1953).

239345 U.S. at 70.

240118 U.S. 356 (1886).

241 The rationale of Fozoler itself will be available only in the relatively rare instance of a manifestly discriminatory statute. Vagueness analysis, as it is seen throughout the cases, has a wider ambit and may be used to ward against subtler deprivations of individual rights.

242 Indeed, one impatient critic has been driven to insist that the Justices "outlaw the amorphous constitutional doctrine of 'void for vagueness' as a judicial tool. . . . [T] he Court should determine the case on its merits in relation to established constitutional guarantees, rather than evade constitutional issues on the ground of 'vagueness." " Note, 23 IND. L.J. 272, 285 (1948).

243 Smith v. California, 361 U.S. 147, 153 (1959) (dictum). Consider the suggestion in Douglas v. Jeanette, 319 U.S. 157, 165 (1943), that the need for federal equitable intervention in that case has been obviated by the Court's holding in Murdock v. Pennsylvania, 319 U.S. 105 (1943), and note the factual differences between the two cases. As regards a licensing statute vesting unfettered discretion in an administrative official, presumably the regulation is indefinite as to every person who might wish to engage in the licensed activity. Kunz v. New York, 340 U.S. 290 (1951). See cases cited note 190 supra.

244 See United States v. CIO, 335 U.S. 106, 150-51 (1948) (Rutledge, J., concurring).

245 E.g., Joseph Burstyn, Inc. v. Wilson, 343 U.S. 495, 505-06 (1952) ; Winters v. New York, 333 U.S. 507, 518, 520 (1948); Cantwell v. Connecticut, 310 U.S. 296, 307-08 (1940); Thornhill v. Alabama, 310 U.S. 88, 98 (1940); Schneider v. State, 308 U.S. 147, 165 (1939). 
alternative syntaxes are available, an election to cast decision in the mold of vagueness is in effect a determination of the direction in which state law must subsequently move.

Comparison of the Yick Wo case with Hague v. CIO ${ }^{246}$ illustrates this point. Both were collateral proceedings to defeat the enforcement of local ordinances. ${ }^{247}$ In both, the ordinances invested executive officials with ill-demarked discretion to grant or withhold licenses: $Y i c k W{ }^{\prime}{ }^{248}$ required "consent" of a board of supervisors for the operation of a laundry in a wooden building; Hague's ${ }^{240}$ demanded a "permit" from the director of public safety for the conduct of public parades or assemblies in streets, highways, parks, or public buildings. ${ }^{250}$ In the records of both cases the evidence was overwhelming that these regulations had been implemented by discriminatory administration: in Yick $W o$, a concerted effort to drive Chinese laundrymen from San Francisco was shown; in Hague, a systematic scheme of police terrorism to keep labor union organization out of Jersey City. ${ }^{251}$ Mr. Justice Matthews, in Yick Wo, was quite evidently troubled by the very existence, on paper, of an ordinance which left the personal liberties of the individual to the "mere will and pleasure" 252 of its administrators. But he felt that in the case before him the Court was

not obliged to reason from the probable to the actual, and pass upon the validity of the ordinances complained of, as tried merely by the opportunities which their terms afford, of unequal and unjust discrimination in their administration. For the cases present the ordinances in actual operation, and the facts shown establish an administration directed so exclusively against a particular class of persons as to warrant and require the conclusion, that, whatever may have been the intent of the ordinances as adopted, they are applied by the public

246307 U.S. 496 (1939).

${ }^{247}$ Hague was a federal district court injunction suit to restrain enforcement of several Jersey City ordinances. Yick $W_{0}$ was a state habeas corpus proceeding to free the petitioner, arrested for violation of a San Francisco ordinance; its companion case, Wo Lee v. Hopkins, was a federal habeas corpus proceeding.

248 San Francisco, Cal., Order No. 1569, May 26, 1880; San Francisco, Cal., Order No. 1587, July 28, 1880.

249 Jersey City, N. J., Ordinance of April 15, 1930, § 3.

250 In the Yick Wo ordinance, executive power was unqualified by any standards for its exercise. The Hague ordinance provided that a permit should be refused only to prevent "riots, disturbances or disorderly assemblage," a standard which the Court regarded as sufficiently vague to permit the "arbitrary suppression of free expression of views on national affairs, for the prohibition of all speaking will undoubtedly 'prevent' such eventualities." 307 U.S. at 516.

251 In Hague the district court made a finding of discriminatory enforcement which the court of appeals affirmed as supported by the evidence. Hague v. CIO, 101 F.2d 774 (3d Cir. 1939). In Yick $W o$ the prisoner showed that 200 of 240 Chinese wooden laundries were denied licenses, while only one of 80 white wooden building laundrymen was similarly refused "consent" 118 U.S. at 359. The lower federal court in Wo Lee found that this constituted discrimination, although it felt constrained to follow the state court's decision in $Y i c k W o_{0}$ in denying relief.

252118 U.S. at 368. 
authorities . . . with a mind so unequal and oppressive as to amount to a practical denial by the State of that equal protection of the laws. . . .253

Hague came up a half century later, after the development by the Court of the vagueness doctrine and the first tentative applications of the concept of indefiniteness to freehand licensing regulations. Here the perspective was inverted. The actual incidence of discrimination was taken only as evidentiary of the potentiality for arbitrary exercises of state power which the ordinance concealed. The primal evil was the form of the regulation itself- "uncontrolled official suppression . . . cannot be made a substitute for the duty to maintain order" 254 -and the ordinance was declared "void upon its face." 255 While it would have been competent for the San Francisco supervisors to continue enforcement of its wooden laundry regulation after Yick Wo provided that they manage to avoid any (judicially provable) discrimination, Hague told Jersey City without equivocation that its entire scheme was impermissible. Necessarily the city repealed its ordinance and enacted a new measure, ${ }^{256}$ which in effect withdrew all discretion from officials. ${ }^{257}$

Hague and Yick Wo, differing in the extent to which they tell a state what it may not subsequently do, illustrate half the picture. Vagueness analysis voids a form of regulation and forecloses its future use, however fairly administered. But because a vagueness decision does address itself to the form of regulation, without reference to the ultimate amenability to regulation of its subject, vagueness analysis also has implications for what a state may subsequently do. As contrasted with De Jonge or Fiske, which mark out spheres of first amendment immunity, Hague v. CIO, ${ }^{258}$ Thorn-

\section{Id. at 373.}

254307 U.S. at 516.

255 Ibid. In fact, the judgment of the Court modified the decree issued by the federal district court below, which had presumed to dictate the manner in which the Jersey City ordinance might henceforth be administered. That decree had ordered officials to refrain from obstructing the right of the unions to hold public meetings in the parks so long as the unions made appropriate application for a permit under the ordinance, and "provided further that such permit may be refused . . . only for the reason that the particular time or place designated in the application is in reasonable conflict with the public recreational purposes of said parks." Hague v. CIO, 101 F.2d 774, 791, 795 (3d Cir. 1939) (appendix). Said the Supreme Court: "We think this is wrong. As the ordinance is void, the respondents are entitled to a decree so declaring and an injunction against its enforcement. . . They are free to hold meetings without a permit and without regard to the terms of the void ordinance" 307 U.S, at 518.

256 Jersey City, N.J., Ordinance of July 6, 1939.

257 See Freund, The Supreme Cont and Civil Liberties, 4 VAND. L. Rev. 533, 553 (1951). Subsequently, finding actual discrimination in the record in Niemotko v. Maryland, 340 U.S. 268, 272 (1951), the Court again adopted the Hague approach. And note that Mr. Justice Murphy remarked on evidences of discriminatory enforcement in Thornhill. 310 U.S. at $98 \mathrm{n.11}$.

258307 U.S. 496 (1939). 
hill v. Alabama, ${ }^{259}$ and Winters v. New York ${ }^{260}$ leave open a field for state experimentation in other modes of control. In Joseph Burstyn, Inc. v. Wilson, ${ }^{261}$ for example, the Court denied New York the power to employ "sacrilegious" as a standard of moving picture censorship, eight of the Justices agreeing that the indefiniteness of the term reserved too wide a latitude for unreviewable administrative discretion. ${ }^{262}$ Commercial Pictures Corp. v. Regents of Univ. of N.Y. ${ }^{263}$ decided per curiam on the authority of Burstyn, apparently made the same determination as regards "immoral." 264 Under the pressure of these decisions, the New York legislature amended its censorship law to specifically define "immoral" as intended "to denote a motion picture film or part thereof, the dominant purpose or effect of which is erotic or pornographic; or which portrays acts of sexual immorality, perversion, or lewdness, or which expressly or impliedly presents such acts as desirable, acceptable or proper patterns of behavior." ${ }^{265}$ The censor then refused to license "Lady Chatterly's Lover," the New York Court of Appeals approved, ${ }^{268}$ and the new provision came before the Court in Kingsley Int'l Pictures Corp. v. Regents of Univ. of N.Y. ${ }^{267}$ Again suppression of the film was held unconstitutional. But this time at least eight ${ }^{268}$ members of the Court felt compelled to find that New York's officials had crossed the line of "free speech" immunity. The majority, reading the court of appeals' opinion as a declaration that the statute condemned portrayal of the "idea" of the acceptability of adultery, employed a De Jonge approach and ruled that suppression of films characterized solely by that incident was beyond state power. $\mathrm{Mr}$. Justice $F_{r a n k f u r t e r}$ and $M r$. Justice Harlan, concurring separately, thought that the New York court had meant its statute to reach only seductive or enticing portrayals. Since this class of subject matter was, they believed, suppressible within the police power, only a Fiske-type inquiry was appropriate. After examining the film, they were prepared to invalidate the

258310 U.S. 88 (1940).

260333 U.S. 507 (1948).

261343 U.S. 495 (1952).

262 See Mr. Justice Douglas' opinion for the majority, 343 U.S. at 504-05; Mr. Justice Frankfurter's concurrence at 530-31. Mr. Justice Reed alone concurred on the ground that the particular film suppressed was within the sphere of first amendment protection. 343 U.S. at 506-07. (1954).

263 Reported with Superior Films, Inc. v. Department of Educ, 346 U.S. 587

264 See Commercial Pictures Corp. v. Regents of Univ. of N.Y., 305 N.Y. 336, 113 N.E.2d 502 (1953).

265 N.Y. EDuc. LAw § 122a.

266 Kingsley Int'l Pictures Corp. v. Regents of Univ. of N.Y., 4 N.Y.2d 349, 151 N.E.2d 197, 175 N.Y.S.2d 39 (1958). Note the insistence in the opinion that the New York law "required" the censor to deny a license to an immoral film. Id. at 355,151 N.E.2d at 200, 175 N.Y.S.2d at 43. Such insistence seems to imply that the necessity for an action, once an agency finds the indefinite prerequisites to action met, obviates all problems of overwide discretion.

287360 U.S. 684 (1959).

$208 \mathrm{Mr}$. Justice Clark's opinion suggests some reliance on an alternative ground of vagueness similar to Burstyn. See 360 U.S. at 701-02. 
censor's decision, "because in applying the New York law to 'Lady Chatterly's Lover' it applied it to a picture to which it cannot be applied without invading the area of constitutionally free expression." 268 Thus, although the spheres of immunity drawn by the majority and the Frankfurter-Harlan positions are of different degrees of inclusiveness and differently characterized, both represent the erection of absolute limits of power.

\section{Conclusion}

If the analyses suggested in this Note are sound, the concept of indefiniteness and its appurtenant doctrines have been developed and used by the Court precisely to obviate-perhaps only temporarily but hopefully permanently-the need for even such narrowly drawn decisions of ultimate power as Kingsley Pictures. Indefiniteness is, after all, a creature of due process; and it is the essence and cardinal aim of due process to minimize the frequency and gravity of those occasions, in a society, when it is necessary to reach the issue of ultimate power. "Ordered liberty" 270_both halves of the rubric are critical. Can order and liberty be reconciled somewhere short of the poles at which terror of slavery, on the one hand, and terror of social disintegration, on the other, assert their categorical demands for the sacrifice of one of these values to the other? Is it possible to evolve adjustments of order and liberty at points of equilibrium where all competing pressures are satisfied, instead of carrying every conflict to the far extremes of emergency at which a choice of one or the other must be made? The premise of due process seems to be that for the very great majority of situations an adjustment is possible and that, given regular procedures, the working forces of a culture will arrive at such an adjustment-if only it is not the cultural habit to rush at once to ultimates in every case. The matter is largely one of methodology.

Vagueness analysis represents methodology on several levels. Functionally it is a means for securing the Court's control over the methods by which governmental compulsion may be brought to bear on the individual. In this aspect it involves an appraisal of the states' methodology from the perspective of probable regularity of operation in the light, in any given case, both of the subject matter's inherent amenability to regulation by articulate uniform rule, and of the seriousness of what is at stake if regulation is left nonuniform and happens to work erratically. But structurally vagueness analysis is also a method in itself-a patterned methodization of the means which the Court employs to effect this control. The method is in part an inevitable product of the attitude which informs the Court's reviewing function; that questions as to the existence of constitutional power are not to be treated as raised by any controversy which may involve merely the manner of the power's exercise. Equally important, the method

269 Mr. Justice Frankfurter, concurring, 360 U.S. at 695. (1937).

$270 \mathrm{Mr}$. Justice Cardozo for the Court in Palko v. Connecticut, 302 U.S. 319, 325 
is a product of doctrine. In its operation it meshes with other doctrines, principally those of standing and scope of review, to assure both flexibility and orderliness in the process of constitutional adjudication.

This doctrinal aspect deserves a concluding emphasis. The Court does not (Mr. Justice Frankfurter has put it aptly) "sit like a kadi under a tree dispensing justice according to considerations of individual expediency." 271 It must maintain a self-imposed order as strict as that which it expects to enforce. It cannot (though it has the power) indulge in irregular forays of intervention into state schemes of regulation, with the announced objective of ensuring their regularity. True, it has on occasion done so. Rochin v. California ${ }^{272}$ was avowedly such a case, and Konigsberg v. State Bar ${ }^{273}$ was probably another. What these cases demonstrate is the obvious, unhappy truth that fifty states can find more ways in which to be irregular than the regular processes of judicial logic and the regular procedures of the Court's appellate jurisdiction can entirely cope with. The same unhappy truth has faced the Court in many of the vagueness cases. But here-unlike Rochin and Konigsberg, where the effort at rationality was more or less overtly given up-the Court was able to fill the breach with a new set of formulas. Their purpose was to regularize the battery of exceptions from ordinary doctrinal regularities which the exigencies of a number of somewhat analogous, but also somewhat dissimilar, cases were demanding. The developed products_-"void for vagueness," "indefiniteness and ambiguity," the attack of a statute "on its face"-reveal the stresses of their origin. Here what the Court has said and what it has done have not always hung together. But neither do the results of the cases, as a body, show that "capriciousness" with which they have been charged. ${ }^{274}$ In the Supreme Court, at least, the "indefiniteness" doctrine has been used to definite and unambiguous ends.

A. G. A.

271 Terminiello v. Chicago, 337 U.S. 1, 11 (1949) (dissenting opinion).

272342 U.S. 165 (1952). Compare Irvine v. California, 347 U.S. 128 (1954).

273353 U.S. 252 (1957). Compare Beilan v. Board of Pub. Educ., 357 U.S. 399 (1958); Lerner v. Casey, 357 U.S. 468 (1958).

274 Note, 23 Ind. L.J. 272, 283 (1948); see Collings, Unconstitutional Uncertainty-An Appraisal, 40 CORNELL L.Q. 195, 196 (1955). 